University of California, Hastings College of the Law UC Hastings Scholarship Repository

Faculty Scholarship

$8-2017$

\title{
The Hounds of Empire: Forensic Dog Tracking in Britain and its Colonies, 1888-1953
}

Binyamin Blum

blumb@uchastings.edu

Follow this and additional works at: https://repository.uchastings.edu/faculty_scholarship

Part of the Comparative and Foreign Law Commons, and the Legal History Commons

\section{Recommended Citation}

Binyamin Blum, The Hounds of Empire: Forensic Dog Tracking in Britain and its Colonies, 1888-1953, 35 Law and History Review 621 (2017).

Available at: https://repository.uchastings.edu/faculty_scholarship/1503

This Article is brought to you for free and open access by UC Hastings Scholarship Repository. It has been accepted for inclusion in Faculty Scholarship by an authorized administrator of UC Hastings Scholarship Repository. 


\section{The Hounds of Empire: Forensic Dog Tracking in Britain and its Colonies, $1888-1953$}

BINYAMIN BLUM

\section{Introduction}

On February 23, 1938, a Jerusalem Military Court convicted Mustafa Mansour of the unlawful possession of a weapon and for opening fire at a bus. The prosecution's key witness tying Mansour to the shooting was, however, not human but canine. Due to darkness the police could not pursue the "brigands" immediately following the incident. They returned at dawn accompanied by Doberman Pinschers. The dogs tracked footprints from the

Binyamin Blum is an assistant professor at The Hebrew University of Jerusalem. For their helpful comments and insights on this Article, the author thanks Hadar Aviram, Susanna Blumenthal, Ian Burney, Simon Cole, Elizabeth Dale, Jared Elias, Robert Gordan, Sarah Barringer Gordon, Ariela Gross, Christopher Hamlin, George Fisher, Lawrence Friedman, Marc Galanter, Miri Gur-Arye, Christopher Hamlin, Ron Harris, Badi Hasisi, Adam Hofri, Amalia Kessler, Roy Kreitner, Thomas Laqueur, Shai Lavi, Sophia Lee, Assaf Likhovski, Setsuo Miyazawa, Kjell Modeer, Projit Mukharji, Neil Pemberton, Christopher Roberts, Richard Ross, Lena Salaymeh, Reuel Schiller, David Schorr, Mitra Sharafi, and Barbara Young Welke, as well as participants of the Hebrew University Law Faculty Seminar, the University of California-Hastings Faculty Seminar, the Tel Aviv University and University of Minnesota Legal History Workshops, The University of Pennsylvania Legal History Consortium and the Stanford Junior Faculty Workshop. This research was supported by the Israel Science Foundation (Grant No. 1751/15). 
crime scene to the defendant's village, and then to his house, where the police discovered a few rounds of ammunition, some of which were spent. ${ }^{1}$

Mansour's conviction was hardly unique in its heavy reliance on dog tracking. ${ }^{2}$ Nor were such evidentiary practices confined to military courts. Despite their known shortcomings, Dobermans became a central feature of policing and proof in 1930s Palestine. Judges routinely relied on such evidence to establish guilt and in some cases - such as that of Mansourto send defendants to the gallows. ${ }^{3}$

The increased reliance on dog tracking was part of a broader shift in crime detection and proof in Palestine, and in the British Empire more generally. Beginning in the late nineteenth century, forensic sciences came to dominate trials in British- administered territories. The colonies often pioneered forensic innovation and its integration into the legal process. State-run forensic laboratories operated in British dependencies such as Ceylon and Egypt decades before they did in Britain. ${ }^{4}$ As a result, when designing Britain's forensic laboratories in the 1930s, the Home Office drew on the expertise of colonial officials such as C.T. Symons, the Government Analyst of Ceylon and Sydney Smith, Principal Medico-Legal Expert to the Ministry of Justice in Egypt. ${ }^{5}$ The colonies also pioneered particular forensic techniques such as fingerprinting, tool marking, and dog tracking. Some of these methods were employed in the colonies long before being introduced if at all - in Britain. ${ }^{6}$

Reliance on forensic innovations in the colonies was not always the result of advances in scientific research. Many novel forms of proof depended on unproven assumptions about the uniqueness of physical

1. "Trial of Arab Charged with Firing at Jewish Bus," Palestine Post, February 23, 1938, 2; and "Arab Sentenced to Death in Jerusalem: Convicted for Firing at Jewish Bus," Palestine Post. February 24, 1938, 2.

2. "Death Sentence for Murderer who Threw Bomb in Haifa," Hatzofeh (in Hebrew), March 22, 1939, 4; and "Five Years for 13 Rounds," Palestine Post, January 5, 1938, 3.

3. "Has Caught You At Last: Two Arabs Sentenced to Death for Murder of Mendel Mintz," Palestine Post, December 15, 1937, 1; and "Villager Sentenced to Death for Firing," Palestine Post, April 29, 1938, 2.

4. Norman Ambage and Michael Clark, "Unbuilt Bloomsbury': Medico-Legal Institutes and Forensic Science Laboratories in England Between the Wars," in Legal Medicine in History, eds. Michael Clark and Catherine Crawford (Cambridge: Cambridge University Press, 1994), 293. See also Sydney Smith, "Medicolegal Institute, Cairo, Egypt," Methods \& Problems of Medical Education, Ninth Series (New York: Rockefeller Foundation, 1928).

5. Ambage and Clark, "Unbuilt Bloomsbury," 293, 299.

6. For the history of fingerprinting, see Chandak Sengoopta, Imprint of the Raj: How Fingerprinting Was Bom in Colonial India (London: Macmillan, 2003); Simon A. Cole, Suspect Identities: A History of Fingerprinting and Criminal Identification (Cambridge, MA: Harvard University Press, 2001), 60-96. For tool marking, see Sydney Smith, "The Identification of Firearms and Projectiles," British Medical Journal (January 1926): 8-10. 
attributes (such as human scent, fingerprints and hair), and the ostensible distinctiveness of mass-produced objects (such as shoes or firearms). ${ }^{7}$ Furthermore, some methods of proof were devised not by "men of science" in the laboratories of Britain's leading research institutions, but by "men on the spot," administrators in the remotest corners of the Empire, grapplingoften intuitively - with the pragmatic challenges of colonial policing in a desperate effort to maintain or restore order.

This article contributes to a growing body of literature that explores colonialism's role in shaping modern forensic culture. ${ }^{8}$ Whereas in the imperial metropole introducing investigative innovations was often met with considerable resistance, there were fewer qualms about doing so abroad. ${ }^{9}$ The inhibiting forces of public opinion were not as influential in the colonies, making experiments in law and policing easier to realize overseas. ${ }^{10}$ Furthermore, at least from a British perspective, colonial policing presented certain exigencies not present — or at least not as forceful—in the metropole. Existing scholarship has convincingly linked the advent of forensic culture to growing social mobility, anonymity, and fears of mass violence. ${ }^{11}$ Colonialism further compounded such metropolitan concerns. Cultural distance in the colonies rendered criminal motives opaque and incomprehensible to British minds. ${ }^{12}$ Mutual distrust between colonizer

7. For a critique of the scientific foundation of "pattern identification disciplines," see Jennifer L. Mnookin,Simon A. Cole, Itiel E. Dror, Barry A. J. Fisher, Max Houck, Keith Inman, David H. Kaye, Jonathan J. Koehler, Glenn Langenburg, D. Michel Risinger, Norah Rudin, Jay Siegel, and David A. Stoney, "The Need for a Research Culture in the Forensic Sciences," UCLA Law Review 58 (2011): 725. For a discussion of how certain kinds of expertise adopted scientific trappings to acquire admittance into American courts, see Jennifer Mnookin, "Scripting Expertise: The History of Handwriting Identification Evidence and the Judicial Construction of Expertise," Virginia Law Review 87 (2001): 1723-1845.

8. For a discussion of "forensic culture" from a historical perspective, see Ian Burney, David A. Kirby, Neil Pemberton, "Introducing Forensic Cultures," Studies in History and Philosophy of Biological and Biomedical Sciences 44 (2013): 1-3. For a preliminary sketch of how colonialism helped shape "forensic culture" see Christopher Hamlin, "Forensic Culture in Historical Perspective: Technologies of Witness, Testimony, Judgment (and Justice?)" Studies in History and Philosophy of Biological and Biomedical Sciences 44 (2013): 4-15.

9. Neil Pemberton, "Bloodhounds as Detective': Dogs, Slum Stench and Late-Victorian Murder Investigation," Cultural and Social History 10 (2013): 69-91.

10. For a discussion of how Utilitarians used India to advance ideas that were considered too dangerous or too revolutionary for England, see Eric Stokes, The English Utilitarians and India (Oxford: Clarendon Press, 1959).

11. Cole, Suspect Identities, 6-31. For a discussion of how this process was reflected in detective fiction, see Lawrence Friedman and Issachar Rosen-Zvi, "Illegal Fictions: Mystery Novels and the Popular Image of Crime," UCLA Law Review 48 (2000-2001): 1411-30, at 1423-24.

12. See, for example, Sydney Smith, Forensic Medicine: A Text-Book for Students and Practitioners (Philadelphia: P. Blakiston's Son \& Co., 1925), 471 ("Motive, which plays 
and colonized bred fear of looming insurgency, native mendacity, and noncooperation. Coupled with the difficulty of cross-racial identification, such distrust meant that nowhere was anonymity so pronounced, and the fear of mass violence so profound, as in the colonies. These factors lent urgency to exploring new methods for investigating crimes; urgency they lacked in the metropole, where criminals - though occasionally ruthless - were at least presumed to act "rationally." 13

Forensic science addressed such anxieties directly by rendering crime scenes legible. Perpetrators could be prosecuted even if no eyewitnesses had been present or were willing to come forth, and regardless of whether the police could comprehend the criminal's motives. Moreover, forensic evidence offered a semblance of objectivity and precision, which helped to legitimize an imposed colonial legal order. Forensic sciences also served Britain's "civilizing mission," substituting European "science"-or pseudoscience - for native superstition, in the service of law and order.

Beyond these featuers, dog tracking also displayed some distinctive traits, which complicate and nuance our view of precisely how colonialism helped redefine the boundaries of forensic innovation. First, tracking relied on olfaction, a sense that to this day remains the least understood scientifically of the five senses ${ }^{14}$ Whereas this underexploration posed challenges to dog tracking's adoption at home, it did not hinder its use in the colonies. Second, unlike other trace evidence, scent by its very nature could not be preserved for fact finders to evaluate at trial, forcing them to defer entirely to testifying experts. Third, unlike other forms of forensic expertise, dog tracking employed an animal, which presented a host of other issues: beyond the difficulty of scrutinizing their method and the grounds for their opinion, dogs possessed a cultural significance and produced (or

so Prominent a part in connection with Western crime, is often difficult to understand in the East, for murders of an extremely revolting nature may have what appears to be a most insignificant motive.")

13. For a discussion of the seeming irrationality of crime in the Middle East, see Frederic M. Goadby, Commentary on Egyptian Criminal Law and the Related Criminal Law of Palestine, Cyprus and Iraq (Cairo: Government Press, 1924), 18-20. For a literary treatment of the irrationality of foreign crime in the work of Conan Doyle, see Ronald R. Thomas, Detective Fiction and the Rise of Forensic Science (Cambridge: Cambridge University Press, 1999), in particular ch. 13 ("Foreign Bodies in A Study in Scarlet and The Sign of Four.)"

14. "NSF Awards $\$ 15$ Million to Crack the Olfactory Code," National Science Foundation, September 21, 2015. http:/www.nsf.gov/news/news_summ.jsp? cntn_id=136333 (accessed June 1, 2017); "Scientists Win \$6.4 Million to Crack the Code of Smell Navigation," Berkeley News (Online), September 24, 2015. http://news.berkeley. edu/2015/09/24/smell-navigation-grant/ (accessed June 1, 2017) ("Olfaction is one of the last frontiers of neuroscience, the least understood of the five senses"). 
were believed to create) certain psychological effects, in both Britain and in its Empire. But whereas these effects hindered their use in Victorian Britain, they only enhanced the dogs' appeal to colonial authorities endeavoring to curb native crime.

The article proceeds in four parts. Drawing on archival material from the United Kingdom, South Africa, and Palestine, it compares dog tracking's trajectory in Britain and in two of its dependencies during the first half of the twentieth century. Part I examines the scientific and moral limitations that led Victorians to reject dog tracking as an investigative technique. Dog tracking was however, enthusiastically adopted in the Union of South Africa during the first decades of the twentieth century, which is the focus of Part II. Citing racial and environmental differences between Britain and its colonies, authorities in South Africa harnessed native superstition of dogs to curb criminality and to elicit confessions from suspects. Similar prejudices characterized dog tracking's adoption in 1930s Palestine, a process analyzed in detail in Part III. But whereas in South Africa canines were employed primarily to investigate livestock theft, in Palestine they were used mostly to address "political" crime. This tendency peaked during the Arab Revolt (1936-39): in the absence of willing and reliable eyewitnesses, canine evidence was routinely offered in court. Despite the reliance on dog-tracking evidence abroad, such proof was deemed insufficiently trustworthy for the metropole. Part IV explores the Home Office's failed efforts from the 1930s onward to establish dog tracking's scientific foundation in a manner that would satisfy English evidentiary standards. The story of dog tracking thus highlights the duality in both moral and scientific standards between forensic inquiries in Britain and in its empire.

\section{Dog Tracking in Victorian Britain}

\section{A. Scents of Identity}

Canine identification abilities have been the subject of literary celebration for millennia. In Homer's Odyssey, only Argos was able to recognize the disguised Odysseus upon his return to Ithaca. ${ }^{15}$ In Sir Walter Scott's

15. Homer, The Odyssey, trans. Robert Fagles (New York: Penguin, 1996), 364.

"Infested with ticks, half-dead from neglect

Here lay the hound, old Argos.

But the moment he sensed Odysseus standing by,

He Thumped his tail, nuzzling low, and his ears dropped..." 
Talisman, a dog identified the thief of the royal standard. ${ }^{16}$ Dogs also played key roles in Victorian literature, perhaps most notably in the tales of Sherlock Holmes. In The Sign of Four, Holmes enlisted the help of Toby, a "queer mongrel with a most amazing power of scent" whose assistance he preferred to "the whole detective force in London." 17 Although Watson was skeptical Toby could follow a scent for kilometers, even through the well-trodden streets of London. ${ }^{18}$ In The Adventure of Shoscombe Old Place, Holmes inferred from the black spaniel's bark that Lady Beatrice's brother had disguised himself as his late sister to fool his creditors. ${ }^{19}$ In Silver Blaze, the dog's failure to bark indicated that the horse thief must have been someone familiar to the dog, thus providing the key to solving the mystery. ${ }^{20}$

Unlike their owners, these literary canines were not misled by outward appearances. Because of their keener senses, they were able to accurately ascertain identity in ways unfathomable to humans. Especially in an era of ubiquitous disguise and social and geographical mobility, verifying identity proved elusive yet critical not only for policing but also for enforcing social boundaries. ${ }^{21}$ As the work of Conan Doyle illustrates, the idea of using dogs to track criminals fascinated Victorians. ${ }^{22}$ Still, dogs were not employed by the police to track perpetrators based on physical evidence found at crime scenes. ${ }^{23}$ Although dog breeders and handlers were occasionally consulted in individual investigations, until the mid-twentieth century such joint ventures were rare. ${ }^{24}$

16. Sir Walter Scott, Talisman (New York: Feather Trail Press, 2009), ch. 24, 140.

17. Sir Arthur Conan Doyle, The Sign of Four, in The Complete Sherlock Holmes (New York: Doubleday, 1960), 115.

18. Ibid., 119.

19. Sir Arthur Conan Doyle, The Adventure of Shascombe Old Place, in The Complete Sherlock Holmes, 1101.

20. Sir Arthur Conan Doyle, Silver Blaze, in The Complete Sherlock Holmes, 335.

21. Cole, Suspect Identities, in particular ch. 1 ("Impostors and Incorrigible Rogues"). For the manifestation of such anxieties in Victorian fiction, see Thomas, Detective Fiction, 63.

22. Pemberton, "Bloodhounds as Detectives," 70.

23. Charles F. Sloane, "Dogs In War, Police Work and Patrol," Journal of Criminology and Police Science 46 (1955): 385-95, at 391. To the extent that the police employed dogs, they were used only to track known individuals (such as fugitives) or to accompany them on patrol.

24. Neil Pemberton, "Hounding Holmes: Arthur Conan Doyle, Bloodhounds and Sleuthing in the Late-Victorian Imagination," Journal of Victorian Culture 17 (2012): 454-67, at 455; Neil Pemberton, "The Bloodhound's Nose Knows? Dogs and Detection in Anglo-American Culture." Endeavour 37(4) (2013): 196-208, at 196. 


\section{B. The Scientific and Moral Limitations of Dog Tracking}

One hindrance was skepticism concerning dogs' ability to reliably track humans, especially in densely populated cities. ${ }^{25}$ Dog tracking's accuracy rested on three fundamental assumptions: first, that every human possessed a unique scent; second, that canines could accurately distinguish between individuals; and third, that dogs could be trained to communicate such distinctions to their handlers. However, comprehensive scientific experiments conducted in Germany and in the United States during the first quarter of the twentieth century challenged these assumptions. ${ }^{26}$ As discussed in Part IV, British researchers struggled to establish them well into the 1950s.

Equally important, dog tracking also violated broadly held cultural beliefs. ${ }^{27}$ In an age when "Menfolk. . . prefer to assume that odourlousness is the standard to be aimed at," the fact that individuals possessed a unique scent was something that "no well bred person likes to think about or discuss." 28 Moreover, scent itself was regarded to be a highly subjective sense. As Grant Allen observed in 1877, "Of all the senses of man, Smell is the one which is least intellectual and most purely emotional."29

Moral apprehension presented another difficulty. Aversion to stalking humans with bloodhounds stemmed in large part from their checkered past in the antebellum American South, as depicted in literary works such as Uncle Tom's Cabin and Dred, ${ }^{30}$ and their role in suppressing insurrections in Jamaica and Cuba. ${ }^{31}$ Though advocates of dog tracking in Britain distinguished the mongrel, savage, man-hunting Confederate "Cuban Bloodhound" (which some argued was no bloodhound at all)

25. "The Bloodhound Question," The Standard (London) October 8, 1888.

26. Wallace Craig, "The Dog as Detective," Scientific Monthly 18 (1924): 38-47; C.J. Warden and L.H. Warner, "The Sensory Capacities and Abilities of Dogs," Quarterly Review of Biology 3 (1928): 1-28.

27. On the significance of odor in Victorian England, see Jonathan Reinarz, Past Scents: Historical Perspectives on Smell (Urbana, IL: University of Illinois Press, 2014), 166.

28. "What Every Dog Knows," Palestine Post, December 30, 1934.

29. Grant Allen, Physiological Aesthetics (London: Henry S. King \& Co. 1877), 83. See also, Janice Carlisle, Common Scents: Comparative Encounters in High Victorian Fiction (Oxford: Oxford University Press, 2004), 27.

30. Edwin Brough, "The English Bloodhound," The Standard (London), October 8, 1888 ("I find that most people have the impression that the Bloodhound is a savage, treacherous brute. I think that this idea is the result of recollections of 'Uncle Tom's Cabin,' 'Dred' and books of that kind. The Cuban Bloodhound, which was used for slave hunting, was a savage animal. . but this is quite a different breed to our Bloodhound..."). See also, Pemberton, "Bloodhound's Nose"; Pemberton, "Bloodhounds as Detective." For an analysis of how this image endured well into the late 1930s, see "The Delicate Bloodhound," Times, (London) March 3, 1938, 15.

31. "Bloodhounds as Detectives," Evening Telegraph (Sheffield), October 8, 1888, 1. 
from its reliable and humane English namesake, ${ }^{32}$ stalking humans still suffered from a beastly image. ${ }^{33}$

Jack the Ripper's 1888 wave of murders represented a flashpoint in the public debate on employing tracking dogs in Britain, illustrating the moral dimensions of this issue. The slayings prompted Sir Charles Warren, Chief Commissioner of the Metropolitan Police, to test the bloodhounds' humantracking abilities in Hyde Park, with the intention of unleashing them in Whitechapel to track the Ripper. ${ }^{34}$ The press, however, reacted with outrage. The Pall Mall Gazette deemed Scotland Yard's proposed use of the hounds "The reign of lawless law," 35 whereas the Evening Telegraph regarded it to be the "perversion of justice and the oppression of liberty." 36 Unleashing hounds in the empire's capital to stalk even the most brutal of murderers was considered repugnant. ${ }^{37}$ Ultimately, even during the "Autumn of Terror," bloodhounds were never employed.

The qualms that precluded dog tracking in Britain did not extend to its dependencies. Moreover, as in the Confederate South, racial distinctions allowed the necessary cultural, epistemological, and scientific space for dog tracking to thrive first in South Africa, and then in Palestine, Kenya, and elsewhere in the British Empire.

\section{The Empire's New Dogs: Canine Tracking in South Africa}

The Natal Police were the first to employ tracking dogs. In 1908 Detective-Sergeant Ker of the Criminal Investigation Department (CID) imported "Rex" to assist him in criminal investigations. ${ }^{38}$ In the following

32. Supporters of bloodhounds" employment sometimes referred to them as "Sleuth Hounds" to both avoid their association with the Cuban Bloodhound and their sanguine connotations. "Bloodhounds as Detectives," Evening Telegraph (Sheffield), October 8, 1888, 1.

33. Edwin Brough, "The English Bloodhound," Standard (London), October 8, 1888, 2 ("The Cuban Bloodhound, which was used for slave hunting, was a savage animal... but this is quite a different breed to our Bloodhound."); "The Old English Bloodhound," Liverpool Mercury, October 9, 1888, 5 ("Our English Bloodhound is infinitely superior."); and "Fallacies About the Bloodhound," Evening Telegraph (Sheffield), December 27, 1888.

34. "Sir Charles Warren Hunted by Bloodhounds: Experiments in Hyde Park," Evening Telegraph (Sheffield) October 9, 1888, 3.

35. "A Ballad of Bloodhounds," Pall Mall Gazette, October 9, 1888, 5.

36. "Bloodhounds as Detectives," Evening Telegraph (Sheffield), October 8, 1888, 1.

37. Pemberton, "Bloodhound's Nose," 207; and Pemberton, "Bloodhounds as Detective," 87.

38. "Reporter Versus Bloodhound-Exciting Chase in the City: How Criminals are Tracked," The Natal Witness (Pietermaritzburg), Saturday, August 21, 1909; and "K-9 100," e-Nongqai 2 (2011), 11. Available at: https://ssur.com/hennieheymans/docs/enongqai_2_vol_8c_k-9_100_(accessed June 1,2017). 
years, "Bashful" and several other bloodhounds joined Rex on the Natal force. Transvaal followed soon thereafter by establishing its own dog unit. ${ }^{39}$

News of the bloodhounds traveled quickly throughout the newly established Union of South Africa. In 1911, one of the bloodhounds was summoned to Johannesburg to demonstrate its capabilities to the South African Police (SAP) authorities. Despite "perfect weather conditions" prevailing in Johannesburg that day, the hound failed miserably. Assuming that the "bloodhound might have been somewhat off-colour on that particular day," another demonstration was scheduled in Pretoria a few days later; however, the bloodhound did no better the second time, leading Acting Police Commissioner H.C. Bredell to deem the entire affair "a complete fiasco." Told that the "dog had done some good work" prior to his arrival, Bredell pondered why "the moment we appear on the scene, the dog will not or cannot do its work." 40 In November, Bredell allowed the hounds a third opportunity to display their talents, but both dogs proved unable to follow the spoor of the white men who had laid it. ${ }^{41}$ Officials explained that race was the true culprit: the handlers had been instructed "to train the dogs to track natives only." 42 Still, the hounds failed even when put on the trail of a "native labourer." 43

Dismayed by the English bloodhounds' poor performance, the force turned to Doberman Pinschers instead. ${ }^{44}$ The Dobermans were found to be the "most useful and reliable breed" possessing the finest combination of sagacity, stamina, and olfactory capacities. The SAP selected "outstanding trained dogs from a line of ancestors famed for brains, grit, and vitality,

39. "The Hound in Peace and War," Nongqai, June 1910, 469; and Marius de Witt Dippenaar, A History of the South African Police, (Silverton: Promedia Publications, 1988), 41.

40. National Archives of South Africa (hereafter: NASA) JUS/136/25435.10 (Acting Commissioner Bredell to Transvaal Police, March 28, 1911).

41. The Merriam-Webster dictionary defines spoor as "a trace by which the progress of someone or something may be followed."

42. NASA SAP/66/CONF/8.665 (Secretary of Transvaal Police to Office of the Commandant Depot, November 15, 1911).

43. Ibid.

44. I.P. de Villiers, "Dogs as Detectives in South Africa," Police Journal 2 (1929): 18892, at 190; NASA JUS/863/1.140.25 (Sub-Inspector in Charge, C.I.D, Bulaway, 4.9.1913): "Steps were then taken to obtain the services of a class of dog which would work successfully under the climatic conditions in this Province." Two police officers then in England were dispatched to the Continent "to obtain full information and, if considered advisable, purchase three Police dogs." After visiting Germany, France, Belgium, and Holland, they returned with two trained and one untrained Doberman Pinschers at the cost of $£ 18$ and $£ 30$ per head, depending on pedigree and training. 
endowed with a strong scenting nose." ${ }^{45}$ These dogs, it was said, could reliably track even 72 -hour-old spoors left by natives. ${ }^{46}$

In 1911, a dog-training facility was erected at Quaggapoort, outside Pretoria, on the farm of General Jan Smuts. ${ }^{47}$ During their 18 month training, the dogs were taught to obey, to retrieve hidden objects, and to follow day-old, several-kilometer-long trails, laid in dry veldt by "natives." 48 For cases in which a trail led to a multioccupant dwelling, or where an object belonging to the suspect was found at the scene, the dogs were trained to match scents and to choose suspects at identification parades. ${ }^{49}$ After successfully completing their training, the Dobermans were dispatched to outposts throughout the Union. ${ }^{50}$ By 1920, the unit was sixty-five dogs strong. ${ }^{51}$ In 1929, with thirteen trainers and 140 dogs in training, Chief of Police I.P. de Villiers noted that South Africa's dog training facility remained "the only state-owned institution of the kind in the world." 52

De Villiers described some of the cases in which dogs solved otherwise insoluble mysteries. In one livestock theft case, the tracks were nearly a week old, and the trail more than 50 miles long. Still, "Trix" successfully led police to a man possessing "two sheep skins and some fresh fat." Although purely circumstantial, the tracking and possession were found sufficient to indict and convict. The defendant was sentenced to 2 years' imprisonment with hard labor. ${ }^{53}$

Still, some officers had misgivings about the dogs' accuracy. ${ }^{54}$ Following a 1918 case in which two dogs tracked the same suspect from the point of breaking and entering, the Deputy Commissioner of police for the Johannesburg District expressed his skepticism. "I contend that it is impossible for a dog to take the scent... and trace accused as was done in this case... I do not wish to convey that the dog handler is

45. Keith Shear, "Police Dogs and State Rationality in Early Twentieth Century South Africa," in Canis Africanis: A History of Dogs in Southern Africa, eds. Lance van Sittert and Sandra Swart (Leiden: Brill, 2008), 193-216, at 208.

46. de Villiers, "Dogs as Detectives," 189.

47. Dippenaar, A History of the South African Police, 41; "K-9 100," 11.

48. de Villiers, "Dogs as Detectives," 189.

49. Sloane, "Dogs In War," 390.

50. Shear, "Police Dogs and State Rationality," 207.

51. Dippenaar, A History of the South African Police, 41.

52. de Villiers, "Dogs as Detectives," 188.

53. Ibid., 192.

54. NASA SAP $92 / 1 / 3 / 23 / 2$. An anonymous letter sent to the police claimed that Sub-Inspector Donald of Hospital Hill had authored a number of unfavorable accounts of the tracking dogs, believing that "these police dogs must be done away with." (anonymous to Officer in Charge, Police Kennels Irene, November 10, 1918). 
unscrupulous, but I honestly confess that I do dislike any person being deprived of his liberty by arrest under such conditions." 55

For obvious reasons, such dissent, as well as the dogs' failures, were actively concealed from the public. After the "fiascos" of 1911, public demonstrations were conducted sparingly, for fear of tarnishing the canines' image. As one observer explained, "since no dog is infallible a public demonstrated failure will cause considerable harm." 56 Now, such demonstrations focused on the dogs' agility and "clever tricks," not on their tracking skills. ${ }^{57}$ However, not all mistakes could be concealed. A 1919 case that received considerable public attention strongly suggested that "dogs put on trails definitely gave wrong indications." 58

\section{A. The Dark Side of Canine Tracking}

Why did dog tracking thrive in South Africa while failing to take root in Britain? Innocuous explanations - namely, differences in climate, urbanization, and industrialization - were offered by some. Discussing the great success of a dog picking up 4-day-old spoors in South Africa, dog expert H.S. Lloyd explained that in the bush, there was "no motor traffic with its oil leaks and petrol odour to overcome." Similar achievements, he opined, "would have proved impossible in England."59 A 1937 SAP Report noted that even within the Union, "complete success with dogs cannot be looked for in towns or other thickly populated places." 60

More sinister reasons, however, lurked in the shadows: racial difference real or constructed - justified the Dobermans' employment to address the distinctive challenges facing the SAP. ${ }^{61}$ In 1910, the SAP's journal

55. NASA SAP 92/1/3/23/2 (Deputy Commissioner of Police, Johannesburg, to Secretary, SAP, January 12,1918).

56. NASA SAP 95/21/99/26. (Spicer to Colonial Secretary, Nairobi, September 10 , 1927). This case continued to haunt the force for some time, and was discussed in the 1937 Inquiry into the South African Police.

57. See G.H.R. Police Dogs: The Wrong Kind Used-Waste of Public Money," Star (Johannesburg) June 29, 1918 (discussing the dogs' misidentification of two children and the general inability of Dobermans to track).

58. Interim and Final Reports of the Commission of Inquiry Appointed by His Excellency the Governor-General to Inquire into Certain Matters Concerning the South African Police and the South African Railways and Harbours Police (Pretoria: Government Printer, 1937) (hereafter 1937 Report), 69. Still, the Commission of Inquiry noted that since 1919, "training and control of the dogs has vastly improved."

59. H.S. Lloyd, "The Value of Dogs to the Police," Police Journal 13 (1940): 206-22, at 209.

60. 1937 Report, 69.

61. Martin Chanock, The Making of South African Legal Culture, 1902-1936: Fear, Favor and Prejudice (Cambridge: Cambridge University Press, 2001), 51. Throughout its 
Nongqai noted that like some of its counterparts in the American South, the Natal force was using dogs to "hunt down bare-footed negroes." 62 Nongqai displayed a keen awareness of the bloodhound's image, notimg that the breed was "sometimes regarded as a ferocious monster, endowed with miraculous attributes, and capable of pursuing his victim successfully under any conditions till caught, when he would certainly tear him limb from limb." The journal conceded that this image was partly derived from the bloodhound's name, which was "calculated to inspire awe, and partly by recollections of slave-hunting tales in 'Uncle Tom's Cabin." 63 But the dogs' petrifying effect did not preclude their use. The journal concluded that "To anyone fond of hound work, man-hunting has an especial charm. . and the pleasures of success are proportionately gratifying." 64

The "charms" and "pleasures" of man hunting were reserved, however, for African quarries. The dogs had not even been trained to track Europeans. ${ }^{65}$ Dog tracking data from South Africa confirms that canines tracked almost exclusively non-whites: of sixty-eight investigations before 1922 for which documentation survives, dogs identified European quarries in only four cases. ${ }^{66}$ Further analysis links this racial imbalance to the crimes that the dogs investigated: primarily livestock theft, a crime allegedly perpetrated overwhelmingly by Africans against Europeans. ${ }^{67}$

Authorities cited numerous factors to elucidate why Africans were supposedly inclined to steal livestock. A 1937 report explained that Europeans provided natives with insufficient meat rations, and the native's "craving for meat" was only intensified by the "kaffir beer" which "many farmers allow[ed] their natives to brew." ${ }^{18}$ Moreover, the report noted the "inherent propensity for theft in certain kinds of natives," especially the unemployed who harbored "no love for work." 69

With annual export values approaching $£ 20,000,000$, livestock farming was "one of the most important industries in the Union." 70 Widespread

early years, the SAP struggled with policing the vast territory with only a small police force, but this became particularly challenging during the Great War, as many were recruited for military service.

62. "The Hound in Peace and War," Nongqai, June 1910, 469.

63. Ibid.

64. Ibid.

65. On the relation between odor and otherness, see Jonathan Reinarz, Past Scents: Historical Perspectives on Smell (Urbana, IL: University of Illinois Press, 2014), in particular ch. 3 ("Odorous Others: Race and Smell").

66. NASA JUS 863 1/139/25 ("Reports on Work Done By Police Dogs," 31.12.1922)

67. 1937 Report, 63.

68. Ibid., 67.

69. Ibid., 64.

70. Ibid., 63. 
theft threatened to destroy this trade entirely. From 1933 to 1937, white settlers reported between 18,000 and 21,000 thefts per year, of which between 2,000 and 3,000 cases annually remained "undetected." Some farmers were forced "to give up the farming of sheep altogether." 71 Stock theft was a persistent problem in other African colonies. ${ }^{72}$ Perhaps more than any other crime, stock theft reflected tensions between Africans and European settler populations. ${ }^{73}$ As one British children's book put it quite plainly, "since black people were not strong enough to drive white strangers out, they stole their cattle and ruined their houses whenever they had a chance." 74

White farmers accused the SAP of inadequately responding to stock theft. They complained "that there are not sufficient detectives specially trained to investigate stock thefts in the areas particularly affected." ${ }^{.75}$ Beyond the difficulty of patrolling large swaths of countryside, prosecuting native stock theft posed unique challenges. First, according to police accounts, stealing from Europeans was not stigmatized in indigenous communities, which made witnesses difficult to procure. ${ }^{76}$ Second, culprits proved particularly elusive. As one magistrate explained, the "efficient pursuit of Bushmen" required "superhuman powers": "Bushmen when fleeing pursue such devious paths that the direct distance between places is about trebled in following their spoor and to follow this latter at all requires a practical skill which seems almost miraculous to the uninitiated. Traveling in the cool of the night the Bushman can cover almost as much ground as a mounted man can by day." 77

Stock theft also challenged colonial governments seeking to introduce British notions of justice. Frequently unable to pinpoint an individual

71. Ibid., 63.

72. David Anderson, "Stock Theft and Moral Economy in Colonial Kenya," Africa 56 (1986): 399-416.

73. Ibid.

74. Henrietta Elizabeth Marshall, "The Great Witch Doctor," in Our Empire Story: Stories of India and the Greater Colonies (London: Jack Ltd. 1908)

75. 1937 Report, 63; and NASA JUS 822/1/403/24 (Secretary, Free State Agricultural Society to Secretary for Justice, September 29,1924 , requesting that dogs be dispatched to assist in tracking stock thieves).

76. See above, 69. The Report explained that much like the liquor laws and location restrictions, the laws against stock theft were considered by Africans to be tailored for natives only. All such restrictions broadened the chasm between the police and the native population. As the Report noted, "natives regard the police as enemies and persecutors rather than protectors and friends."

77. Martin Legassick, "From Prisoners to Exhibits: Representations of Bushmen of the Northern Cape, 1880-1900," in Rethinking Settler Colonialism: History and Memory in Australia, Canada, New Zealand and South Africa, ed. Annie E. Coombes (Manchester: Manchester University Press, 2006), 63-99, at 72. 
culprit, the government often had to impose, collective punishmentwhich undermined Britains claim to moral authority - or allow such crimes to go unpunished. ${ }^{78}$ Tracking dogs offered a partial solution to such quandaries: even if they could not identify the true culprit, the dogs helped isolate an individual defendant. Police dogs were, therefore, dispatched to the Union districts most affected by stock theft. ${ }^{79}$ The white man's best friend was thus bred to be the colored man's worst enemy.

\section{B. The Psychological Effects of Dog Tracking}

Substantiated or not, the conventional wisdom was that Africans feared dogs and believed they possessal supernatural powers, a belief that the SAP was only too happy to exploit. ${ }^{80}$ The SAP consciously drew on the dogs' effect on local criminals to justify their use. Police reports noted

78. Chanock, South African Legal Culture, at 117. As will be discussed, this did not entirely obviate or prevent the imposition of collective punishment in South Africa or elsewhere. For a discussion of this dilemma in Kenya: "Parliament: Collective Punishment in Kenya Defended," The Times (London, England) November 27, 1952. Goadby, Commentary on Egyptian Criminal Law, 319 (discussing "the abandonment of the 'primitive but effectual' methods which formerly existed of enforcing a sort of communal responsibility for crime." Goadby discusses how this "has directly tended to enhance the difficulties in the way of its suppression and detection, though. . .the advance of civilization has made such abandonment necessary.")

79. For discussions concerning the allocation of dogs to areas most affected by stock theft, see NASA JUS 822/1/403/24 (Commissioner of Police to Secretary for Justice, December 27, 1923; April 23, 1924; August 23, 1924; October 21, 1926).

80. Robert J. Gordon, "Fido: Dog Tales of Colonialism in Namibia," in Canis Africanis: A Dog History of Southern Africa, eds. Lance van Sittert and Sandra Swart (Leiden: Brill, 2008), 173-92, at 188 ("It was an article of faith that Africans were by nature scared of dogs, even if everyone repeated stories about thieves poisoning fierce dogs or making friends with them.") For a discussion of dogs' cultural significance in late nineteenth and early twentieth century Africa see Peter Mitchell, "The Canine Connection II: Dogs and Southern African Herders," Southern African Humanities 26 (2014): 1-19, at 13; John Maclean, A Compendium of Kafir Laws and Customs (London: Cass, 1968; first edition 1858), at 9195; Monica Hunter, Reaction to Conquest: Effects of Contact with Europeans on the Pondo of South Africa (London: Oxford University Press, 1936), 275 (enumerating dogs among the "witch familiars," beings that appear as humans or animals and with which those engaged in witchcraft have "sexual conexion and by means of which they illegally destroy life and property."); and Eileen Jensen Krige, The Social System of the Zulus (Pietermaritzburg: Shuter \& Shooter, 1957; [first ed. 1936]), 325.

For an analysis of dog's liminal nature in the European imagination, see Aaron Herald Skabelund, Empire of Dogs: Canines, Japan and the Making of the Modern Imperial World (Ithaca: Cornell University Press, 2011), 6-7 ("As creatures of metaphor, dogs oscillate between high-status animals and low-status people. They are said simultaneously to possess admirable traits (such as bravery) that make them akin to humans and despicable attributes (such as filth) that render them unalterably inferior - or in the minds of some, like 'Other' humans.") 
with satisfaction the Dobermans" "great impression upon the natives"81 and how "half the effect" was in the "influence they produce on the native mind." 82 An experienced handler, who came to realize the dogs were "a hopeless failure" in identifying perpetrators, observed that Africans selected by the dogs often confessed falsely out of fear. ${ }^{83}$ This was not necessarily a reason not to use canines: if natives believed that dogs possessed such powers, their employment alone could help reduce crime. ${ }^{84}$

That colonial authorities would exploit superstition in this manner was particularly incongruous, given Britain's proclaimed "civilizing mission," which aimed to eradicate witchcraft and traditional medicine and replace them with European science and reason. ${ }^{85}$ Law in particular was trumpeted as "a primary avenue through which the state sought to discipline and deny witchcraft." ${ }^{86}$ The use of dogs only reinforced superstition, further strengthening perceptions of colonial policing and governance as forms of witchcraft. ${ }^{87}$ As a result, dogs in particular came to symbolize European colonialism itself, in both African struggles for independence and in postcolonial literature. ${ }^{88}$

81. NASA JUS 863/1/139/25 ("Reports on Work Done by Police Dogs," October 2, 1914)

82. NASA SAP 95/21/99/26 (Spicer to Colonial Secretary Nairobi, September 10, 1927).

83. Shear, "Police Dogs and State Rationality," 210.

84. For a sociohistorical analysis of the relationship between dogs and social control throughout history, particularly in colonial settings, see J. Robert Lilly and Michael B. Puckett, "Social Control and Dogs: A Sociohistorical Analysis," Crime and Delinquency 43 (1997): 123-47. As Lilly and Puckett note, Doberman Pinschers in particular were not only bred to discipline, but also physical features such as their ears and tails were artificially manipulated to enhance their intimidating appearance. For a discussion of how the British employed dogs to track and maul suspects during the Mau Mau Rebellion, see "Mau Mau Raids Near Mount Kenya," Times, September 27, 1952, 6. See also: Caroline Elkins, Imperial Reckoning: The Untold Story of Britain's Gulag in Kenya (New York: Henry Holt, 2005), 86 (recounting how one interrogator "set his dog at the old fellow. The animal got him to the ground, ripped open his throat, and started mauling his chest and arms. In spite of his screams, my companions just grinned. It was five minutes before the dog was called off.")

85. Katherine Luongo, Witchcraft and Colonial Rule in Kenya, 1900-1955 (Cambridge: Cambridge University Press, 2011), 88-89.

86. Ibid., 91.

87. For a discussion of perceptions of colonial government as a form of witchcraft see Clifton Crais, The Politics of Evil: Magic, State Power, and the Political Imagination in South Africa (Cambridge: Cambridge University Press, 2002).

88. See David Anderson, Histories of the Hanged: The Dirty War in Kenya and the End of Empire (New York: W.W. Norton, 2005), 239 (describing how the loyalist Home Guard was scornfully referred to by their rivals as "the running dogs of British Imperialism" and how Kikuyu rebels nailed headless dogs to government notice boards). For a discussion of $\operatorname{dog}$ 's significance in postcolonial literature, see Wendy Woodward, "Social Subjects: 


\section{Of Human and Canine Trackers}

British reliance on superstition highlights the Doberman's dual nature: it was simultaneously modern and primitive, appealing to both the scientific (or pseudoscientific) sensibilities of colonial officials, and the superstitions and fears - real or attributed - of the native. In the liminal space between science and superstition, culture and nature, domesticity and wilderness, ${ }^{89}$ colonial approaches to dog tracking paralleled British Portrayals of the African and Australian Bushman, American-Indian, Maori, and Bedouin trackers $^{90}$ : all fluctuated, perhaps paradoxically, between quasi-human and superhuman, "Shaman" and "Sherlock." "What they supposedly lacked in intelligence they made up for in keener instincts and intuitions. Being more deeply in tune with their environment, they were capable of observing even the minutest signs in nature. ${ }^{92}$

Representations of Dogs in South African Fiction in English," in Canis Africanis: A Dog History of Southern Africa, eds. Lance van Sittert and Sandra Swart (Leiden: Brill, 2008), 235-62; and Patrick Williams, Ngugi Wa Thiong'o (Manchester: Manchester University Press, 1999), 71 (discussing how in Thiong'o's $A$ Grain of Wheat, African Lieutenant K's rape of white Dr. Lynd is replaced by the killing of her dog). See also, Brendon Nicholls, Ngugi Wa Thiong'o, Gender, and the Ethics of Postcolonial Reading (Burlington: Ashgate, 2010), 110. Against this background, it becomes clear why in 2012 South African President Jacob Zuma referred to black Africans' ownership of pet dogs as an attempt to "emulate whiteness." See AP: "South Africa: A Biting Critique of Pets," New York Times, December 27, 2012, 8. http://www.nytimes.com/2012/12/28/world africa/south-africas-president-gives-a-biting-critique-of-pets.html? $\mathrm{r}=1$ (accessed June 1, 2017).

89. For an analysis of dog's liminal nature in the European imagination, see Aaron Herald Skabelund, Empire of Dogs: Canines, Japan and the Making of the Modern Imperial World (Ithaca: Cornell University Press, 2011), 6-7 ("As creatures of metaphor, dogs oscillate between high-status animals and low-status people. They are said simultaneously to possess admirable traits (such as bravery) that make them akin to humans and despicable attributes (such as filth) that render them unalterably inferior - or in the minds of some, like 'Other' humans.")

90. On the African Bushmen, see Alan Hattersley, The First South African Detectives (Cape Town: Timmins, 1960), 168 ("Bushmen were the finest trackers in the world. Moreover they could maintain existence under conditions of extreme hardship that would kill any civilised man within seventy-two hours. In the field of detection primitive skills may yet play a significant role.")

91. For a discussion of this motif concerning Native American trackers, see Gina Macdonald and Andrew Macdonald, Shaman or Sherlock? The Native American Detective (Westport, CT: Greenwood Press, 2002).

92. For a discussion of how domestication corrupted the Arab "noble savage" see Toby Dodge, Inventing Iraq: The Failure of Nation Building and a History Denied (New York: Columbia University Press, 2005). For a similar discussion of how bloodhounds may have "lost their nose," see H.S. Lloyd, "The Value of Dogs to the Police," Police Journal 13 (1940): 206-22, at 210. 
Court decisions in South Africa drew an explicit analogy between indigenous and canine trackers. When considering the admissibility of dogtracking evidence (a topic I will address shortly), judges pondered whether such proof could have been admitted had it been offered by a native tracker who was unable to communicate his findings verbally. Sir Thomas Graham, Judge President of the Eastern Districts Local Division, urged his readers to "Conceive a case where the police possessed the services of a native whose language no one in South Africa understood." 93 However, there was nothing inherently significant about the tracker in Graham's analogy being indigenous; the point would have been equally valid had he chosen a non-native illustration.

Comparisons between canine and native trackers carried over to other locations and contexts ${ }^{94}$ : as one visitor to the dog training depot in South Africa observed, "The South African police dog is, with the possible exception of the Maori Aboriginal, the most wonderful tracker in the world." ${ }^{95}$ British colonial authorities used native trackers alongside canines to reinforce one another. In 1950s Kenya, British forces employed Kikuyu and Sudanese trackers alongside canines to form "Tracker Combat Teams" (TCT) charged with "deep penetration tactics." ${ }^{96}$ Particularly challenging tracking was left, however, to canine rather than native trackers implying the superiority of the former. ${ }^{97}$

Such comparisons between native and canine, as well as their joint employment, bore additional symbolic value. For Britons, one aspect of African savagery was their wanton violence and cruelty towards animals. ${ }^{98}$ By implying that dogs were equal or even superior trackers, British authorities signaled that dogs (and animals more generally) were worthy of the

93. R. v. Kotcho, 1918 (Eastern Districts Local Division) 91-107. Similarly, a Canadian judge wrote: "Let it be supposed that the most skillful of these [natives] was employed to track the murderer, and that he had followed courses such as those taken by the dogs." For Canada, see R. v. White (British Columbia) 1926, 5 D.L.R. 2.

94. When describing the work of his Sudanese tracker Ibrahim, Len Hynds, a British military policeman serving near the Suez Canal, explained: "As I was making notes as to what had been taken, Ibrahim was circling around, sniffing the ground like a dog." Len A. Hynds, "Ibrahim - the Sudanese Tracker, n.d. http:/www.thespeechlesspoet.co.uk/true\%20stories/ desert/brahim\%20-\%20The\%20Sudanese\%20Tracker.html" (accessed June 1, 2017).

95. National Archives of the United Kingdom (hereafter NAUK) CO 733/246/12 (Spicer to Chief Secretary of Palestine, April 11, 1933).

96. Huw Bennett, Fighting the Mau Mau: The British Army and Counterinsurgency in Kenya (Cambridge: Cambridge University Press, 2012), 27.

97. NAUK CO 822/478 ("Use of Wind Scenting Dogs Provided by Colonel Baldwin, a Dog Breeder, by the Kenya Police During the Emergency," 1953).

98. Brett L. Shadle, "Cruelty and Empathy, Animal and Race, in Colonial Kenya," Journal of Social History 45 (2012): 1097-16, at 1099. 
natives' respect and fear. Moreover, dog breeding and training to tracklike colonialism itself - symbolized Britons' ability to tame, master and harness nature. ${ }^{99}$

\section{The Questionable Admissibility of Dog-Tracking Evidence}

Though used broadly by the SAP, dog tracking raised considerable evidenting issues. Not all investigative methods used by the police necessarily yield admissible evidence. Lack of sufficient scientific foundation, for example, might lead to exclusion, effectiveness in investigation notwithstanding. When dogs uncovered physical proof (e.g., stolen goods), such evidence possessed probative value, independently of the fact that dogs had led to it, making its admissibility uncontested. ${ }^{100}$ But could the dog's tracking itself prove a criminal's identity?

The legal debate turned largely on evidentiary classifications. If the dogs were direct witnesses, or experts testifying (by barking and pawing) about a match between spoors detected at the crime scene and the unique scent of the defendant, the admissibility of their "testimony" would have to include cross-examination. If instead they were regarded as sophisticated olfactory devices operated by expert dog masters, their handlers would have to substantiate the scientific principles upon which they operated, with special attention paid to their training and methods.

To support the argument that tracking dogs were mere instruments, South African dog masters emphasized the scientific nature of their methods. They highlighted the canines' intersubject, temporal, and spatial consistency. ${ }^{101}$ To this end, two dogs were brought to every crime scene to ensure that both followed the same trail. ${ }^{102}$ If identification parades were conducted, participants were rearranged to demonstrate the dogs' consistency. ${ }^{103}$ Handling protocols also dictated that "[the handler] should not be informed of the name or the whereabouts of any suspects, nor of the direction in which an offender may be believed to have left the scene of

99. Skabelund, Empire of Dogs, 7.

100. I refer here solely to the evidentiary aspect, rather than to the procedural question of the circumstances under which the police could be allowed to employ dogs, which is beyond the scope of this article. The legality of the search itself was a question addressed in South Africa in Jan Mentor v. The Union Government (Supreme Court, Cape of Good Hope provincial Division, May 18,1926 ) a suit for damages caused in the course of a dog search. See NASA JUS $/ 822 / 1 / 403 / 24$.

101. Shear, "Police Dogs and State Rationality," 197.

102. NASA JUS 863/1/139/25 ("Reports on Work Done by Police Dogs," RCI 6 and RCI 40 of January 20, 1918; RCI 10 of March 1, 1919).

103. NASA JUS 863/1/139/25 (in particular RCI 2 of November 27, 1918; RCI 10 of March 1, 1919). 
the crime." ${ }^{104}$ However, such precautions could not fully control for systemic failures whereby, for example, both dogs consistently - but mistakenly - followed a stronger or fresher scent from the crime scene. ${ }^{105}$

Early on, South African courts generally admitted dog tracking evidence to prove identity. They accepted the position of South Africa's Solicitor General that dog masters were experts who had "studied as a science the movements and habits of police dogs" (emphasis added), rendering the dogs "mere instruments." 106 Based on this understanding, some defendants were convicted based solely on canine evidence. ${ }^{107}$

The first fissures appeared in $R$. v. Kotcho, a 1918 stock-theft case in the East Cape. ${ }^{108}$ The defense attorney argued that dog tracking was inadmissible hearsay: "The dog indicated the prisoner by pawing him. That was the dog's equivalent of speech; it was information conveyed to the police by the dog and subsequently related by them to the Court. It was not evidence on oath, there was no possibility of cross-examination, the dog was not produced and if it were it could not be cross-examined."109

To illustrate its argument, the defense provided an analogy of a deaf, dumb, and blind human tracker with a keen sense of smell, who behaved like a police dog. "Supposing such a man followed up a scent, could it be said that the police would be able to give in evidence the indications this man had given to them?" Moreover, it was argued, even if a dog could speak, its evidence would arguably remain inadmissible, because the animal had not been present during the crime: "the dog was put on the scent in the absence of the prisoner. It was clearly not part of the res gestae as the crime had been completed." Finally, even if the dog was considered an "expert," its evidence was "given second-hand and without any testimony whatever that the person giving it was qualified." 110

Judge Graham excluded on two grounds: first, the dogs' incompetence and second, the court's inability to independently assess their proof. Graham reasoned that "lunatics and persons in state of intoxication were not competent to give evidence on the ground that they were not in a

104. NASA SAP $92 / 1 / 3 / 23 / 2$ (Office of the Commandant to Commissioner of South African Police, October 16, 1928).

105. See Rudolphine Menzel, Dog Education and Training (Palestine: Lanotter, 1939).

106. $R$ v. Kotcho, 1918 (Eastern Districts Local Division) 91-107.

107. NASA SAP/92/1/3/23/2 (Secretary, South African Police, April 11, 1918, citing $R$. v. Dartheus [Heidelberg] and $R$. v. Sokkins [Pretoria]).

108. R. v. Kotcho, 1918 (Eastern Districts Local Division) 91-107.

109. "Use of Police Dogs-Is Their Evidence Admissible? Interesting Argument in Supreme Court," Grocott's Penny Mail, April 17, 1918 (newspaper clipping available in NASA SAP 92/1/3/23/2).

110. R. v. Kotcho, 91. 
rational state." Therefore, he explained, "an irrational creature like a dog" should be subject to the same standard. He noted that "It would be a dangerous innovation to allow the introduction of the evidence of irrational animals which were actuated by instincts of which we knew but little and could regulate only in a limited degree." 111

Graham went on to explain that even if dogs were considered "rational," with scent there "was something intangible that could not be tested," which distinguished it from other visible and conservable trace evidence (such as fingerprints or footprints). Other trace evidence could be documented and presented in court by experts, for fact finders to form an independent opinion. The ephemeral nature of scent, however, meant that courts had no opportunity to independently evaluate it, forcing them to defer entirely to the dog and its handler. Because the dog master's "testimony was clearly hearsay," even the usual safeguards for ensuring a direct witness's credibility were unavailable in this instance. 112

Kotcho did not however, deal a final blow to the judicial admission of dog-tracking evidence in South Africa. Such proof was offered in legal proceedings until 1920, when the High Court addressed the matter in $R$. v. Trupedo. ${ }^{113}$ The defendant was charged with entering a girls' hostel with the intent to commit a crime. He escaped through a window after one of the three girls in the room awoke. A dog rushed to the scene led its master to a hut in the hostel's yard where eight natives were sleeping. After sniffing all of them, the dog barked at the defendant, who was in bed with a blanket over his head. ${ }^{114}$

In his decision to exclude the dog's evidence, Chief Justice James Rose Innes departed from Graham's reasoning. ${ }^{115}$ Canines' lack of rationality was not, in his opinion, an obstacle to admissibility, but rather quite the contrary. In some cases, Innes wrote, "inferences may be quite properly drawn from the behaviour of animals." 116 For example, a dog's failure to bark upon the entry of an intruder (as in Conan Doyle's Silver Blaze) could lead to a proper inference that the trespasser was someone familiar

111. Ibid.

112. See also: "Movements of Police Dogs," Rand Daily Mail (Johannesburg), Saturday, May 11, 1918. "Police Dogs Not 'Evidence"" Rand Daily Mail (Johannesburg), May 22, 1918) (newspaper clipping available in NASA SAP 92/1/3/23/2).

113. NASA SAP 92/1/3/23/2 (District Commandant, Marico, to Deputy Commissioner, S.A.P. Transvaal Division, Pretoria, 7.10.1919).

114. R. v. Trupedo, 1920 SALR (Appellate Division) 58

115. Ibid., 64.

116. This aspect of the ruling would be later cited and discussed in Poswa v. Christie 1934 SALR (Natal Provincial Division, June 13, 1934), 178. The case involved the behavior of sheep to prove their ownership. 
to the dog. ${ }^{117}$ This was not, however, the case when prosecutors sought to introduce tracking and identification of someone previously unknown to the dog. Distinguishing permissible from impermissible inferences drawn from canine behavior, Innes contrasted behavior that was "instinctive and invariable" and skills for which animals "must be carefully trained before they can be relied upon." 118 Whereas the former were founded on the "instinct of self-preservation," the latter involved "processes closely akin to reasoning." 119 Reasoning and analogous processes were prone to risks of error and, perhaps more significantly, the insincerity of either dog or handler, which rendered them inadmissible.

Innes added that dog's behaviour was exceptionally prone to "misunderstanding between the animal and its keeper", further compounding the general risks of hearsay. Dog tracking also lacked scientific foundation. "We have no scientific or accurate knowledge as to the faculty by which dogs of certain breeds are said to be able to follow the scent of one human being, rejecting the scent of all others." Properly analyzed, he ruled, dog tracking belonged in the "region of conjecture and uncertainty" rather than science, and must therefore be excluded from judicial decision making. ${ }^{120}$

Ironically, judicial exclusion only paved a path toward more sweeping and troublesome uses for dog tracking. During the 1920s, the SAP continued to employ dogs broadly throughout the Union to recover stolen stock and to elicit confessions. ${ }^{121}$ Moreover, soon after the High Court excluded dog-tracking evidence, the government introduced the Stock Theft Act, which reversed the onus of proof in such cases. The new statute provided that "being found in possession of stock reasonably suspected of being stolen and being unable to give a satisfactory account of such possession" was sufficient to convict. ${ }^{122}$ The Act thus deemed it unnecessary to present the dogs' identification in court. ${ }^{123}$ Additionally, dog spooring could lead to

\section{R. v. Trupedo, 63.}

118. Ibid.

119. Ibid. In a sense, Innes's opinion echoed a distinetion made by some between dogs and hounds. See, for example Lloyd, "The Value of Dogs," 206. ("A dog when once he gets to like his handler and is properly trained, works for the pure love of pleasing his handler... The hound, on the other hand, seems to work entirely on his own, by inherited instinct, and has little or no affection for his handler, or any desire to please him, but hunts to please himself.")

120. Ibid., 63.

121. de Villiers, "Dogs as Detectives." The legitimacy of such a use was specifically singled out by Judge Graham in Kotcho. See NASA SAP 92/1/3/23/2 (Secretary, South African Police to all S.A. Police units concerned, July 13, 1918).

122. Chanock, South African Legal Culture, at 123.

123. For a discussion of such employment of the dogs, see "Evidence of Police Dogs," Star (Johannesburg) March 6, 1925. 
punitive extrajudicial measures. In some provinces "Spoor Laws" allowed collective fining of entire kraals to which dogs had tracked stolen stock. In 1937, such measures were recommended throughout the Union. ${ }^{124}$

Despite the inadmissibility of their evidence, the SAP's Dobermans were a sought-after crime-detection technology throughout the British Empire. From South Africa, the Dobermans performed cross-border tracking of criminals into neighboring Batusoland, Swaziland, and Bethuanaland. ${ }^{125}$ Wishing to establish their own canine units, between 1918 and 1939 police forces in Southern Rhodesia, ${ }^{126}$ Kenya, ${ }^{127}$ Palestine, ${ }^{128}$ India, ${ }^{129}$ Burma, ${ }^{130}$ New Zealand, and Australia ${ }^{131}$ requested that the SAP provide them with dogs and handlers. Inability to complete the demanding handler training, prohibitive costs, and a shortage of trained canines, however, meant that other police forces were seldom able to maintain their own units. Rules pertaining to handlers imposed an additional hurdle: displaying yet another racially discriminatory dimension of dog tracking, only white members of colonial police forces were admitted to South Africa's dog-master training. ${ }^{132}$

\section{Dog Tracking in Palestine}

\section{A. From Rifles to Notebooks}

One of the first police forces outside South Africa to successfully integrate tracking dogs was Palestine. The 1935 establishment of Palestine's Dog Section must be considered against the backdrop of broader reforms that took place in the Palestine Police following the 1929 "disturbances." 133 Claiming nearly 250 lives and leaving an additional 500 injured, the disturbances led authorities to rethink their policing approach. Palestine's government had not only failed to prevent the violence; it had also been unsuccessful in bringing perpetrators to justice. In as many as 420

124. 1937 Report, 68; and Chanock, South African Legal Culture, 254.

125. Shear, "Police Dogs and State Rationality," 205.

126. NASA SAP 386/21/19/46 ("Police Dogs: Rhodesian Police," 1918-1960).

127. NASA SAP 95/21/99/26 ("Police Dogs: Kenya Police," 1927-1947).

128. NAUK CO 733/246/12 (de Villiers to Spicer, March 10, 1933).

129. "The Union's World Famous Police Dogs," Nongqai 9 (1939): 901. The dog unit of the North Western Frontier in India was established in 1939.

130. Lieutenant-Colonel W. Marsh, "Dogs in Jungle War," NASA SAP 296/21/22/38.

131. NASA SAP 296/21/22/38 ("Police Dogs: New South Wales Police" 1938-1945).

132. Shear, "Police Dogs and State Rationality," 205.

133. "Disturbances" is the British term used by the British. In Hebrew the events are commonly referred to as P'raot Tarpat (1929 Pogroms). In Arabic they are known as Thawrat al-Buraq ("The Wall Revolt"). 
indictable offenses, the accused remained "unknown." Furthermore, crimes that were prosecuted resulted in a $40 \%$ acquittal rate. ${ }^{134}$ Critics attributed the government's failure to several factors: the force's size (especially its British contingent of a mere 175) was deemed inadequate, its intelligence service deficient, and its leadership wanting. All these allegedly contributed to the outbreak and escalation of violence. As for the failure to secure convictions, Zionist leaders accused Arab witnesses - including policemen -of perjuring themselves and thwarting justice. ${ }^{135}$

Following the disturbances, Herbert Dowbiggin - inspector general of the Ceylon Police and a renowned authority on colonial policing - was dispatched to Palestine to advise on reforms. ${ }^{136}$ His recommendations were counterintuitive: rather than reconstituting Palestine's militarized gendarmerie (that had been disbanded in 1926), Dowbiggin advocated a further move toward a civilian or "blue" police force. He proposed modeling the Palestine Police on the Metropolitan Police, rather than on the Royal Irish Constabulary that served as the blueprint for most colonial police forces. ${ }^{137}$ According to Dowbiggin's vision, Palestine's policemen would be more educated and better integrated among themselves (Arabs, Jews, and Britons) and within the communities they served. ${ }^{138}$ They would be equipped with notebooks rather than armed with rifles. ${ }^{139}$ Such reforms were part of his broader vision for bridging the gap between state and society, making the colonial police at least appear less coercive or external to the population that they policed. Critics sarcastically commented that such reforms replaced "old mounted warriors" with "pimplyfaced youths from the training school." 140

A major component in Dowbiggin's reform was the restructuring of the CID by enhancing its intelligence-gathering and scientific-analysis capabilities. $^{141}$ Drawing on Ceylon's pioneering experience with employing

134. See Palestine Blue Book for 1929 (Jerusalem: Government Printer, 1930), 343.

135. Israel State Archives (hereafter ISA) P 758/4 ("Report on the Scope, Character and Result of the Judicial Proceedings Upon the August 1929 Riots in Palestine").

136. See Martin Kolinsky, Law, Order and Riots in Mandatory Palestine, 1928-1935 (London: St. Martin's Press, 1993, 100-101.

137. For an analysis of the "Irish Model" and its influence on throughout the Empire, see David M. Anderson and David Killingray, eds. Policing the Empire: Government, Authority and Control, 1830-1940 (Manchester: Manchester University Press, 1991), ch. II in particular.

138. Gad Kroizer, "From Dowbiggin to Tegart: Revolutionary Change in the Colonial Police in Palestine During the 1930s," Journal of Imperial and Commonwealth History 32 (2004): $115-33$.

139. Ibid., 120.

140. Ibid., 119.

141. Ibid., 121. See also: Kolinsky, Law, Order and Riots, 101. 
science in policing, in 1932 a forensic laboratory was established at Palestine Police Headquarters. New technologies allowed the Palestine Police to conduct ballistic, fabric, blood, and semen analyses, and to identify firearm markings. New recruits were trained to collect such specimens from crime scenes. ${ }^{142}$ Edward Horne's claim that "Palestine had one of the first police forces in the world to explore the possibility of forensic science as an aid to detection and conviction" is perhaps overstated. ${ }^{143}$ Forensic laboratories operated for decades in other parts of the British Empire, including in Ceylon and neighboring Egypt. ${ }^{144}$ However, it bears mentioning that the laboratory in Palestine was established before its British counterpart, further suggesting the relationship between colonialism and the development of forensic culture. ${ }^{145}$

Forensic science helped address many of the deficiencies that impeded investigation and prosecution during the 1929 disturbances. It provided the colonial state with direct access to crime scenes, unmediated by the indigenous population, thus freeing it from reliance on native eyewitnesses. The universal language of science also provided a semblance of precision, objectivity, and evenhandedness. This proved particularly significant in Palestine, where British authorities were often accused (by both Arabs and Jews) of partiality. With fresh memories of the police's ineptitude during the 1929 disturbances, and with mounting British fear of recurring unrest, such unmediated access to evidence was deemed critical.

The Dog Section fit neatly within this brave new vision of policing. In his correspondence with the Secretary of State for the Colonies concerning the establishment of a canine unit, High Commissioner Arthur Wauchope explained, "I think that there is no question that the use of dogs would assist the Police considerably in their work, particularly where the investigation of political crime is concerned... [where] information which might be given by members of the public leading to the arrest and conviction of the criminals is often withheld out of fear and a misguided sense of sympathy." 146

The forensic turn, was, however, double edged: by reducing the authorities' reliance on native cooperation, it risked further alienating the local population by rendering them passive objects of surveillance rather than active participants in policing their own communities. Similarly, the expansion of the British web of informants (also advocated by Dowbiggin) bore

142. Ibid., 471.

143. Ambage and Clark, "Unbuilt Bloomsbury," 293-94.

144. Ibid. See also Methods \& Problems of Medical Education, Ninth Series (New York: Rockefeller Foundation, 1928) (Surveying the forensic laboratories around the world in 1928).

145. Ambage and Clark, "Unbuilt Bloomsbury," 293-94.

146. NAUK CO 733/246/12 (Wauchope to Cunliffe-Lister, June 21, 1933). 
the potential of unraveling Palestine's social fabric by spreading fear and distrust. ${ }^{147}$ The turn from rifles to notebooks was, therefore, not entirely consistent with the effort to bridge state and society.

\section{B. Breeding Injustice}

Although the Dog Section must be considered within the context of the broader Dowbiggin reforms, the precise impetus for its founding can be pinpointed to a particular failure by Palestine's human, Bedouin trackers in solving a highly charged political crime: the murder of Dr. Haim Arlosoroff, head of the Political Department of the Jewish Agency. ${ }^{148}$ The prosecution relied on Bedouin trackers' testimony to corroborate the widow's identification of the two defendants. At trial, however, both trackers-Abu Ruz and Abu Irgaig - were impeached by defense attorney Horace Samuel, who laid bare the fallibility of their methods: they had breached identification-parade protocols by inspecting the soles of the defendants' shoes after the widow had identified the two suspects. Moreover, rather than following the alleged murderers, the trackers divulged on cross-examination that they had possibly followed footprints left by the policemen who arrived at the scene before them. ${ }^{149}$ Chief Justice Michael McDonnell concluded that the trackers' evidence should be given no credit. ${ }^{150}$ The acquittals were a painful setback for the Palestine Police. The high profile case placed Bedouin tracking skills under considerable public scrutiny, raising profound doubts concerning their reliability. ${ }^{151}$

147. See, generally, Hillel Cohen, Army of Shadows: Palestinian Collaboration with Zionism, 1917-1948 (Berkeley: University of California Press, 2008).

148. "From Town and Country: Training Boxer Dogs," Palestine Review, April 21, 1939, $6-7$.

149. "Arlosoroff Murder Trial-Trackers' Evidence; Plaster Casts of Footprints," Palestine Post, May 3, 1934, 7. See also Horace B. Samuel, Who Killed Arlosoroff: A Record of Crime and Justice in the Mandated Territory of Palestine (unpublished, 1934), from 34.

150. A.A. 7/1934 Abraham Stavsky v. Attorney General, Palestine Law Reports 2 (1935): $148,150-51$ ("The evidence of the trackers was in many ways unsatisfactory. The undoubted confusion of the tracks which they followed, with tracks showing spur chains that were clearly those of a mounted constable... are enough to make it difficult to accept this evidence, especially in view of the circuitous route followed by the debated tracks... Further, even if the evidence as to tracks on the scene of the crime were unimpeachable, I am satisfied that the foot-print parade on the beach was vitiated by the fact the trackers witnessed the identification parade in the station yard.")

151. Samuel, "Who Killed Arlosoroff?" 62-76. 
Inspector General Roy Spicer (Dowbiggin's protége who was appointed to head the Palestine Police in the wake of the 1929 disturbances) took the exoneration as an opportunity to introduce a canine unit. Weeks after the Supreme Court's acquittal, Sergeant John Kenyon Parker and Constable Alexander R. Pringle of the Palestine Police were dispatched to Pretoria for a dog-master training course. ${ }^{152}$ They returned on Christmas Eve, 1934, with three Doberman Pinschers: Ria, Gift, and Mayer. ${ }^{153}$ Spicer had long awaited a chance to introduce dog tracking: in 1927, while serving in Kenya, Spicer visited the SAP kennels and remained captivated by the Dobermans. ${ }^{154}$ Although he sought to adopt dog tracking in Kenya while serving there, he could not justify the expenditure. ${ }^{155}$ When transferred to Palestine, however, "finding [himself] in a country where the Treasury coffers are full," his plans could be realized. ${ }^{156}$ The failed prosecution in the Arlosoroff case provided the opportunity to import the canines, and make Spicer's "dog dreams... come true."157

To enhance their public image, Palestine's press was enlisted to disseminate favorable accounts of the canines' successes. ${ }^{158}$ Journalists from Palestine's leading English, Arabic, and Hebrew newspapers were summoned to Palestine Police Headquarters in Jerusalem for a public demonstration of the dogs' skills. ${ }^{159}$ On March 1, 1935, The Palestine Post and Davar's front page reported the Doberman's first investigative triumph. According to the article, Gift and Mayer were brought to sniff a jewelry box from which £P.15 (Palestine Pound) were stolen. ${ }^{160}$ Each leading

152. ISA M/335/10. See also R.G.B. Spicer, "The New Detective," Police Joumal 9 (1936): $245-51$.

153. "Police Dogs for Palestine: Officers Return with Trio," Palestine Post, December 24, $1934,10$.

154. Spicer, "New Detective," 245.

155. NAUK CO 733/246/12 (Spicer to Chief Secretary, April 11, 1933).

156. NAUK Metropolitan Police (MEPO) 2/4981 (Spicer to Allan, October 16, 1934).

157. Spicer, "New Detective," 245.

158. Horne, Job Well Done, 456 ("Whenever the dogs had a success, Spicer saw that the fact was widely publicized."). For examples of such publicity see "Police Use Dogs," Davar, March 1, 1935, 1; and "Police Dogs in Salame," Filastin, May 16, 1935, 6.

159. According to reports in the Palestine Post and Filastin, in attendance were journalists from Haaretz, Hayarden, Davar, Doar Hayom, Al-Jamea Al-Islamiya, Al-Difa'a, Filastin, and the Palestine Post. "How Dogs Assist the Police: Jerusalem Journalists Receive a Lesson in Dog Training for Crime Discovery," Doar Hayom (in Hebrew), May 10, 1935, 4; "The Police Dogs," Haaretz, May 5, 1934; J.L. Meltzer, "A Local Departure in Crime Detection: Dogs Used by Palestine Police," Palestine Post, Thursday, May 9, 1935, 3; and "Police Dogs and Crime Detection: Important Press Demonstration," Filastin, May 14, 1935, 5. "Police Hounds Capture Thief," Palestin Post, March 1, 1935, 1.

160. See Robert D. Ottensooser, "The Palestine Pound and the Israel Pound: Transition From a Colonial to an Independent Currency." 
their handlers separately, the two dogs followed identical trails to Dir Yassin, a few kilometers away from the crime scene, where both chose the same individual out of an identification parade. ${ }^{161}$ The Dobermans also conducted demonstrations for incredulous spectators at crime scenes: the dog-masters asked skeptical audience members to hide objects for the dogs to retrieve. ${ }^{162}$

By May 1935, the dogs had assisted in solving twenty-four cases, including four murders, two attempted murders, eleven crimes against agricultural property, one case of stock theft, and three cases of forced entry. ${ }^{163}$ In their first year of operation, the three dogs worked at ninety-nine crime scenes, leading a number of suspects to confess. ${ }^{164}$ They were reputed to have followed 72-hour-old footprints, ${ }^{165}$ and tracked distances of up to 6 kilometers from the initial spoor through terrain bereft of any visible tracks. ${ }^{166}$ In its annual report to the League of Nations for 1935, His Majesty's Government reported: "The Police dogs have frequently been used in detecting the perpetrators of agrarian or other crimes, with an efficacy which has established their value as an aid in the apprehension of offenders and has created a very useful deterrent impression in the minds of villagers." 167 The dogs' fame spread beyond Palestine's frontiers: French authorities in Lebanon soon requested their assistance as well. ${ }^{168}$

Racial prejustice played a less significant role in justifying the dogs' use in Palestine. Not only were the dogs employed in urban areas to track shoed quarries, but Spicer also noted "so far as I know, the Palestine criminal is not more odiferous than criminals in other parts of the world." 169 As a result, Spicer fostered a vision to not only "spread the police dog cult into other Colonies" but also "into the British Police Forces themselves." ${ }^{170} \mathrm{He}$

161. "Police Use Dogs," Davar, March 1, 1935, 1.

162. "Crime-Dogs Solve Crimes," Al-Difa'a, May 9, 1935, 7.

163. "A Local Departure in Crime Detection: Dogs Used by Palestine Police," Palestine Post, Thursday, May 9, 1935, 3; and "How Dogs Assist the Police: Jerusalem Journalists Receive a Lesson in Dog Training for Crime Discovery," Doar Hayom, May 10, 1935, 4.

164. Horne, Job Well Done, 458.

165. Ibid.

166. Ibid. See also: "Police Dog Tracks Robbers: 'Kim' Follows Scent for 6 Kilometers," Palestine Post, September 24, 1945, 3 (The article describes how at dawn Kim followed spoor from the scene where a bus had been held up the previous evening, to the middle of the village of Kaza, where the scent was lost. An identification parade of the village's eleven male inhabitants was then held, where Kim identified Ahmed Hassan.)

167. Report by His Majesty's Government in the United Kingdom of Great Britain and Northern Ireland to the Council of the League of Nations on the Administration of Palestine and Trans-Jordan for the Year 1935 (London: His Majesty's Stationery Office, 1936).

168. "Borrowing Palestine Police Dogs," Palestine Post, October 14, 1935.

169. Ibid.

170. Ibid. 
urged his colleagues to "adopt the Doberman Pincher, see that every country and county has its quota of dog-masters and trained dogs, and you will be able to detect crime in a manner beyond the wildest dreams of Conan Doyle and Edgar Wallace."171

As in South Africa, however, one of the dogs' significant appeals in Palestine was their perceived psychological effect on Palestine's population. In 1935, Spicer noted with satisfaction the "moral effect" that the dogs possessed over the "criminal classes in Palestine," both primitive and sophisticated: "They are regarded with superstitious fear and dread by less educated offenders while the really intelligent criminal realises that they are possibly the most dangerous servants of public security that has yet been encountered."172 Not understanding the dogs" mysterious ways, "primitive" Palestinian criminals reportedly tried every trick, including the wrapping of rags around their feet. ${ }^{173}$

Official correspondence was less explicit about the dogs' religious significance for Palestine's inhabitants. Still, many of those serving in Palestine were keenly aware of the fact that "Muslim Arabs considered dogs to be unclean." 174 Herbert Samuel, Palestine's first high commissioner (1920-25), forbade the entry of dogs into his official residence

171. Ibid.

172. Horne, Job Well Done, 459.

173. Ibid., 458.

174. "British Constable 1069 Howard Mansfield Recalls His Service in Nablus, Jerusalem and Haifa," in The Creation of the State of Israel (Perspectives on Modern World History), ed. Myra Immell (Detroit: Gale, 2010), 159-67. Mansfield served in Palestine from 1946 to 1948. Dogs' precise status in Islam and in Judaism beyond the scope of this article and moves a seperate discussion. Dogs' status in Islam has been contested for centuries, by some accounts dating back to the Prophet himself. Al-Jahiz explained that dogs were considered impure because they were border crossers: they confused the categories of culture and nature, neither a "wild animal nor a domestic one, neither a human nor a jinn (spirit)." See Marion Holmes Katz, Body of Text: The Emergence of the Sunni Law of Ritual Purity, (Albany: State University of New York Press, 2002), 19. Still, as the historical work of Alan Mikhail has demonstrated, dogs played a significant role in Egyptian society until the nineteenth century, their impurity notwithstanding. See Alan Mikhail, The Animal in Ottoman Egypt (Oxford: Oxford University Press, 2014), in particular Part II ("In Between"). However, by the twentieth century, dog ownership was generally regarded unfavorably in the Middle East. See Khaled Abou El Fadl, "Dogs in the Islamic Tradition and Nature," in Encyclopedia of Religion and Nature (New York: Thoemmes Continuum, 2005). El Fadl asserts that dog ownership was largely reserved for Bedouins, who used dogs for protection and herding, and for Westernized elites, for whom dogs symbolized "Europeanization." Dogs' status was similarly contested in Judaism: Deuteronomy prohibited offerings funded by the "hire of a whore or the price of a dog." Dogs were often described as foolish, carcass-eating, bloodthirsty creatures. As in some African traditions, in the Bible, a dog's howling represented a bad omen of death. See Sophia Menache, "From Unclean Species to Man's Best Friend: Dogs in the Biblical, Mishnaic, and 
for precisely that reason. ${ }^{175}$ Despite their imputed impurity, however, the Arabic press - including newspapers known for their critical stance against the British government, such as Al-Difa ' $a$ - applauded the dogs' import (at least initially) as a welcome effort to combat crime. ${ }^{176}$ Crime victimsArabs and Jews alike-soon began demanding that dogs be brought to crime scenes to investigate. ${ }^{177}$

Although imported to address "political crimes," dogs were initially used mostly to address common but otherwise difficult to investigate "agrarian crime" such as tree cutting, crop burning, and animal maiming. ${ }^{178}$ The latter

Talmud Periods"; and Joshua Schwartz, "Good Dog — Bad Dog: Jews and Their Dogs in Ancient Jewish Society," in A Jew's Best Friend? The Image of the Dog Throughout Jewish History, ed. Phillip Lieberman-Ackerman and Rakefet Zalashik (Brighton: Sussex Academic Press, 2013). In Europe, Jews were widely believed to suffer from an irrational fear of dogs, and dog ownership was generally discouraged. As a Yiddish adage suggests, "if a Jew has a $\operatorname{dog}$, either the $\operatorname{dog}$ is no dog or the Jew is no Jew." See Robert A. Rothstein, "'If a Jew Has a Dog...': Dogs in Yiddish Proverbs," in A Jew's Best Friend? By the twentieth century, however, Jewish attitudes towards dog were undergoing a conscious refashioning, at least in some circles. Through a stronger bond with the land and with nature - including animals - the Zionist movement sought to forge a new Jewish identity. Dogs were casted to play a key role in the plan for creating a braver, closer to nature, "New Jew." See Rudolphine Menzel, Dog Education.

175. Tom Segev, One Palestine Complete: Jews and Arabs Under the British Mandate (New York: Henry Holt \& Co. 2000), 197. This changed dramatically by 1938: adjacent to the new Government House a dog cemetery was erected. Ibid., 342.

176. "The Criminal Investigation Department's Amazing Dogs," Al-Difa'a, May 14, 1935, 4; "News of Border Crime: Dogs Detect Culprits," Filastin, April 4, 1935, 5; "Crime Discovered by the Police Dogs: Tree Cutting in Ramallah," Filastin, March 14, 1935; "Dogs Discover Tree Cutting Crime: Track Culprit to Mosque Gates," Filastin, April 2, 1935; "Police Dogs in Salame," Filastin, May 16, 1935, 6; and Assad A-Shakiri, "The Barks of Our Dogs and the Activity of the Foreign Dogs," Filastin, June 23, 1935, 5. Still, some were skeptical as to whether the dogs provided sufficient deterrence and proposed more severe punishment for agricultural crimes. See "Police Dogs and the Custom of Tree Cutting," Filastin, April 10, 1935, 2.

177. "Crime-Dogs Solve Crimes," Al-Difa'a, May 9, 1935; "They Set Fire to Fields and Forests, Chop Down Trees, Throw Stones and Bombs - Yet the Government Remains Silent," Davar, May 4, 1936, 1. Some suggested in jest that the dogs be given their share in rewards for wanted persons, also suggesting that a pension fund be established for their benefit. See "Haifa Notebook," Palestine Post, May 17, 1938, 6.

178. Horne, Job Well Done, 458; J.L. Meltzer, "Local Departure in Crime Detection", Palestine Post, May 9, 1935, 3. ("The animals appear at their best in agrarian crimes or malicious injury to property. .."); and "Destruction of Trees," Palestine Post, 18 October 1935, 4 ("The cutting of the trees of one's enemy is still a common type of revenge in the Tulkarem district, despite the success of the police dogs in tracking down offenders."). This was at least one of their intended uses when brought to Palestine. See NAUK CO 733/246/12 (Wauchope to Cunliffe-Lister, June 21, 1933, mentioning particularly "treecutting [sic] and animal maiming in Arab as well as Jewish villages."). 
in particular was considered by colonial authorities to be one of "the most loathsome habits in this country." 179 To British observers, animal maiming epitomized the cruelty and irrationality of the Levantine delinquent and distinguished him from his British counterpart: such crimes provided no gain, satisfying only base, vengeful instincts through wanton cruelty toward innocent creatures. ${ }^{180}$

Dog tracking, therefore, met a distinctly imperial necessity. Through the prism of Orientalist criminology, the inability to comprehend motives required and justified innovative investigative techniques. ${ }^{181}$ As the Palestine Post noted, crimes such as animal maiming displayed "beastliness of conception with great difficulty of detection and proof," thus rendering them "outside the pale of ordinary police methods." Dogs provided a practical solution complemented by a symbolic significance not lost on contemporaries: "Brutality in humankind is confronted by a super-human intelligence in brute creation. Better still, one dumb creature has it in its power to avenge another." 182

\section{Let Slip the Dogs of War: Suppressing the Arab Revolt}

Palestine's Dog Section reached its heyday during the Arab Revolt (193639), which began 16 months after the Dobermans' arrival and claimed thousands of lives. ${ }^{183}$ To meet increasing demand for canine assistance during the Revolt, "aeroplanes were used in order to transport them expeditiously from one part of the country to another."184 "Arthur's Dogs" (named for Palestine's High Commissioner, Arthur Wauchope) could be

179. "Suppressing a Savage Crime," Palestine Post, June 4, 1935, 4. The article was written after the dogs reportedly tracked down a man who, in an act of revenge, stabbed a mare belonging to the Sheikh of the Sakne tribe.

180. See, for example, Goadby, Commentary on Egyptian Criminal Law, 320 ("crimes of vengeance such as murder, wounding and malicious injuries to property are far more common in Egypt, while in the case of acquisitive crimes such as theft and the like the difference [between England and Egypt] is less startling."); and Sydney Smith, Mostly Murder (New York: D. McKay Co., 1959), 65. ("It is perhaps a sign of civilisation and progress that in more advanced communities crimes of revenge tend to be greatly outnumbered by crimes committed for gain.")

181. Smith, Forensic Medicine, 471 ("Motive, which plays so prominent a part in connection with Western crime, is often difficult to understand in the East, for murders of an extremely revolting nature may have what appears to be a most insignificant motive.")

182. "Suppressing a Savage Crime," Palestine Post, June 4, 1935.

183. Estimates vary and are highly contested, and range between 3,000 and 6,000 Arabs and several hundred Jews and Britons. See Benny Morris, Righteous Victims: A History of the Zionist Arab Conflict, 1881-2001 (New York: Vintage, 2001), 159-60.

184. Report by His Majesty's Government in the United Kingdom of Great Britain and Northern Ireland to the Council of the League of Nations on the Administration of 
instantly transported anywhere in Palestine. Despite its small size, "To the rural villager who decided to break the law, the new dog section now began to appear ubiquitous." 185 Thanks to the Royal Air Force (RAF), from their kennels atop Mount Scopus in Jerusalem, the Dobermans could sniff out criminals in Palestine's most remote districts; that prospect alone - it was hoped - would keep criminals at bay. The British thus merged two powerful technologies of imperial control: dogs and aircraft ${ }^{186}$ (a combination they would repeat in 1950 s Kenya). ${ }^{187}$ In 1936, the dogs were reportedly "successful" in solving 87 of the 172 cases that they helped investigate. ${ }^{188}$

One such tracking took place following an ambush of the York and Lancaster Regiment on August 29, 1936. A search party discovered the dead body of an Arab in possession of a rifle and a clip of cartridges. The dogs were "brought to the scene by aeroplane" and given scent, after which they followed an 8 kilometer trail. "He gave tongue in the house of an Arab villager. In the house was found a large stock of explosives, powder and lead, together with a photograph of the dead man." 189 If the official report is to be believed, more compelling confirmation of the dog's tracking accuracy could hardly be imagined.

As the Arab Revolt entered its second, more violent phase in September 1937, the Secretary of State for the Colonies dispatched Charles Tegart (former commander of the Calcutta Police), and David Petrie (director of intelligence for India and subsequently Head of MI5) to advise the Palestine Police. Titling the fourth section of their report "Dogs," Tegart and Petrie deemed the Dobermans indispensable for combatting "Arab terror." 190 "The trained instinct of these animals achieves results which are

Palestine and Trans-Jordan for the Year 1936 (London: His Majesty's Stationery Office, 1937), 121.

185. Horne, Job Well Done, 459.

186. For an analysis of the British use of airplanes in the Middle East, and Iraq in particular, see Priya Satia, Spies in Arabia: The Cultural Foundations of Britain's Covert Empire in the Middle East (Oxford: Oxford University Press, 2008). See also David Killingray, "A Swift Agent of Government': Air Power in British Colonial Africa, 1916-1939," Journal of African History 25 (1984): 42944.

187. NAUK CO $822 / 478$ ("Use of Wind Scenting Dogs Provided by Colonel Baldwin, a Dog Breeder, by the Kenya Police During the Emergency," 1953). See also: "Mau Mau Raids Near Mount Kenya," Times (London) September 27, 1952, 6.

188. Report on the Administration of Palestine, 1936, at 121.

189. Marsh, "Dogs in Jungle War," NASA SAP 296/21/22/38

190. NAUK CO 733/383/75742/77 (Report of Sir Charles Tegart and David Petrie, January 24, 1938) (hereafter Tegart \& Petrie Report). Some have mistakenly attributed the introduction of Dobermans to the Tegart Report itself. See Laleh Khalili and Jillian Schwedler, "Introduction," in Policing and Prisons in the Middle East: Formations of Coercion, eds. Laleh Khalili and Jillian Schwedler (London: Hurst \& Co. 2010) 15. 
quite beyond the highest human intelligence," 191 they observed. Tegart and Petrie were relying not only on second-hand accounts or the dogs' reputation but on an investigation that they had themselves accompanied: in January 1938 archeologist J.L. Starkey was murdered outside Hebron by "Arab bandits." Tegart and Petrie saw the dogs lead detectives from the murder scene on a 22 kilometer trail through mountainous terrain, from Beit Jibrin to Kharass, ultimately leading the police to a weapon concealed in a wall. ${ }^{192}$

Noting the shortage of Dobermans in Palestine, Tegart and Petrie recommended increasing the size of the Dog Section. Even with the RAF at their service, the Dobermans could not meet demand. ${ }^{193}$ Tegart observed that in 1937 only ten of fifty calls for assistance from Hebron were met. ${ }^{194}$ As a result, many crimes went unsolved. "Consideration of time, economy in transport and escort, as well as the health of the dogs themselves" required increasing the number of dogs significantly and spreading them more evenly throughout the country. The report recommended that there "be a complete and self-contained establishment in Nazareth" with the aim of eventually establishing independent dog units in Nablus and Haifa as well. 195

Tegart and Petrie linked the need for more dogs to declining public cooperation, thus underscoring the particular necessity for novel detection methods during periods of colonial unrest. "In every case where tracks are left, there is, with dogs, a good chance of success and without them a virtual certainty of failure, assistance from the public being rarely forthcoming." 196 Dog tracking replaced eyewitness accounts, which grew scarcer as public support for the colonial government declined. ${ }^{197}$ "There is nothing more likely to put an end to acts of sabotage and violence than tracking by dogs," the report determined. Tegart and Petrie concluded: "The question

191. Tegart \& Petrie Report.

192. "Investigations into Murder on Beit Jibrin Track: Dogs on Trail of Highwaymen," Palestine Post, January 12, 1938, 1; and "Several Arrests in Starkey Murder Investigation," Palestine Post, January 13, 1938, 1.

193. Four additional dogs were purchased in 1937. Report by His Majesty's Government in the United Kingdom of Great Britain and Northern Ireland to the Council of the League of Nations on the Administration of Palestine and Trans-Jordan for the Year 1937 (London: His Majesty's Stationery Office, 1938), 111.

194. Tegart \& Petrie Report.

195. Ibid.

196. Ibid.

197. For a discussion of Bedouin resistance to British rule during the Arab Revolt, see Mansour Nasasra "The Southern Palestine Bedouin Tribes and British Mandate Relations, 1917-48: Resistance to Colonialism" The Arab World Geographer 14 (2011): 305-35; and Mansour Nasasra, "Memories from Beersheba: The Bedouin Palestine Police and the Frontiers of Empire," Bulletin for the Council of British Research in the Levant 9 (2014): 32-38. 
of dogs we regard as of the utmost importance and urgency in the matter of restoring law and order." 198

To implement Tegart and Petrie's recommendations, the Palestine Police acquired eight Dobermans and commissioned two South African dog masters at great expense. ${ }^{199}$ A new kennel was built in Affula, which "greatly increased the efficiency of the section. Dogs can now arrive at the scene of a crime in any part of the country within two hours of being requisitioned."200 The investment seemed imperative: with waxing anticolonial sentiment and waning public cooperation, police dogs had become indispensable.

The canines' success, however, brought professional risks. Fear of poisoning meant that tracking dogs were generally prohibited from taking food from strangers. ${ }^{201}$ During the Arab Revolt, the Dobermans increasingly became targets of attack. ${ }^{202}$ The police responded by providing the dogs with armed escorts and thoroughly investigating any harm suffered by them. Migdal's death prompted an autopsy to determine whether the dog had been poisoned. He was found, however, to have died of "heart failure following a chill." 203

The demand for Dobermans increased in 1938. Following Migdal's death, Tegart recommended the purchase of four more Dobermans. ${ }^{204}$ But South Africa could spare no more, declining requests not only from Palestine but from other parts of the Empire as well. ${ }^{205}$ The Secretary of

198. Tegart \& Petrie Report.

199. Report by His Majesty's Government in the United Kingdom of Great Britain and Northem Ireland to the Council of the League of Nations on the Administration of Palestine and Trans-Jordan for the year 1938 (London: His Majesty's Stationery Office, 1939), 113.

200. Ibid.

201. "Dogs as Detectives in South Africa," Argus (Melbourne), October 6, 1934, 6.

202. Horne, Job Well done, 458. See also: "Two gang members killed during attack on cars on road to Nablus," Davar, July 10, 1938, 3 (Davar was reporting the third incident in which police dogs were targeted); and "After the Dogs," Palestine Post, November 22, 1937, 6. ("The effectiveness with which the police bloodhounds [sic] have been doing their work has attracted the ire of the gunmen whom they are called upon to track down, often with success.")

203. ISA M 335/10 (Autopsy Report, March 3, 1938). The analyst added that "The Dog [sic] was employed on a long and arduous trail of some 25 kilos in the Acre Sub-District" and "was off colour on his return and on the sick list from the date of his return."

204. NAUK CO 733/358/6 (Telegram from High Commissioner to Secretary of State, April 1, 1938).

205. NASA SAP 296/21/22/38 (GRC Baston to Commissioner of Police, New South Wales, 1.9.1938: "Whilst I am always willing to assist other Police Forces in the Empire in the matter of police dogs, I regret exceedingly that at the moment, and for the next eighteen months, I shall be quite unable to spare you any dogs at all owing to the very heavy drain on us by the Palestine Force.") 
State for the Colonies' personal appeal to then South African Deputy Prime Minister Jan Smuts - whose farm initially housed the dog depot - proved futile, and other alternatives had to be explored. ${ }^{206}$ Importing dogs from Germany posed both practical and political challenges: as a memorandum to the Secretary of State pointed out, the dogs "would have been trained in German." 207 More importantly, by 1938, for Britain to request the assistance of Nazi Germany was no trivial matter, with tensions mounting over the fate of Sudetenland. As one Colonial Office official noted, there was great irony in the "rather curious position that we should be seeking the aid of the German Government in acquiring animals designed to track down Arabs who murder Jews." ${ }^{208}$ But as the Arab Revolt intensified, His Majesty's Government overcame its qualms, ultimately purchasing three trained dogs from a breeder in Hamburg. ${ }^{209}$

Dog tracking often justified extrajudicial punitive action in Palestine. ${ }^{210}$ As one British soldier reported home, "You may follow the police dogs into one village and upon this vague clue you may smash the village and burn it down." ${ }^{211}$ His account was not hyperbole. Following the November 5, 1937 killing of two "Black Watch" soldiers near Jerusalem's Jaffa Gate, Dobermans led the forces to Silwan, where soldiers beat twelve civilians to death with rifle butts. ${ }^{212}$ Similarly, after rebels ambushed and killed an RAF officer in February 1938, a dog led British forces to a house in the village of Ijzim, but when put on the scent again, the dog led to a house opposite the one it had originally marked. Rather than allowing the inhabitants of both homes the benefit of the doubt, both houses were reduced to rubble and the entire village was fined. ${ }^{213}$

\section{Trial by Canine}

When first introduced, the Palestine Police announced publicly that the dogs' "function is not so much to produce evidence, as to corroborate the circumstances of crimes, as naturally dog testimony is admissible in

206. Ibid. (Minute by Downie, June 20, 1938).

207. Ibid. (Memorandum to Secretary of State, June 20, 1938).

208. Ibid.

209. Ibid. (Chief Secretary to Downie, August 2, 1938). Two dogs and one bitch were purchased for a cost of Reichmark (RM) 475 each (the equivalent of £P. 40).

210. Matthew Hughes, "The Banality of Brutality: British Armed Forces and the Repression of the Arab Revolt, 1936-1939," English Historical Review 124 (2009): 31354. See also: "Attack on Post," Palestine Post, April 21, 1938, 1; and "Attacks on Traffic" Palestine Post, April 10, 1938, 2.

211. Hughes, "The Banality of Brutality," 327.

212. Ibid., 346.

213. Ibid., 326. 
no court."214 Even dog enthusiasts such as Rudolfine Menzel, founder of the Palestine Canine Research Institute, expressed skepticism about dogtracking's "scientific foundation" (wissenschaftliche fundierung). ${ }^{215}$ In her 1938 book on dog training, Menzel observed that dogs typically followed the most recent - and hence strongest - scent that they encountered. It was therefore not uncommon, she noted, for a dog to follow tracks for kilometers, finally leading to the home of a policeman who had investigated the crime scene. Contrary to laypersons' beliefs, she noted, even the most talented dog could not simply sniff an object and lead its handler to the criminal. At most, dogs might retrieve other clues that could in turn help the police identify the culprit or yield other admissible evidence. ${ }^{216}$

Menzel's own experience with the Palestine Police Dog Section provided grounds for skepticism concerning their reliability: in at least two instances in which Menzel arrived at murder scenes (often hours before the Palestine Police), her tracking dogs followed entirely different trails than the police's Dobermans. This suggested that a dog's training and handler significantly influenced the path followed and the person identified. ${ }^{217}$ Other incidents provided additional grounds for doubts: in one robbery case, the dogs identified an old blind man, who clearly could not have committed the crime. ${ }^{218}$ Critics alleged that at identification parades the canines always picked out someone, even if the perpetrator was not present. $^{219}$ Given their lack of verbal skills, the dogs' choice of a suspect could not be adequately explored. Once a person was selected, however, police were accused of invariably "discovering" additional incriminating evidence. 220

214. "A Local Departure in Crime Detection: Dogs Used by Palestine Police," Palestine Post, May 9, 1935, 3.

215. Haganah Archive (hereafter HA) $34 / 289$ (Address by Menzel to Haganah staff, 1939).

216. Menzel, Dog Education, 135.

217. Central Zionist Archive (hereafter CZA) 129/67.

218. Middle East Centre Archive, St. Antony's College, Oxford (hereafter MEC), Jerusalem and East Mission (hereafter J\&EM), LXVI/3 (Re: Abdul Hafiz Abdullah et. al.) ("May I humbly point out that so far in the history of investigation in Palestine, whenever police dogs taken [sic] to a parade after having a scent, they have never, I repeat, so far, failed to pick one or more persons out of the parade. One might argue that this is due to the shining detective mentality of our C.I.D. men. Unfortunately however I know of a case of theft, where dogs after being given scent followed the scent and arrived to a distant village, entered the room an old bling [sic] man and barked at him, meaning to say that this is the person who committed the robbery.")

219. Ibid.

220. Hughes, "The Banality of Brutality," 326. 
Despite the Palestine Police's commitment not to offer canine evidence in judicial proceedings, prosecutors soon began relying on such proof at trial. Neither the novelty of the method nor skepticism concerning its reliability led the judiciary to exclude it. Two dogs could corroborate each other's identifications. Houses were demolished and some defendants were sent to the gallows based solely on dog identifications. ${ }^{221}$

Adding to concerns regarding their reliability, those interpreting the dogs' behavior in court were often not even their handlers. ${ }^{222}$ Given the high demand for their skills, Parker and Pringle-Palestine's only certified dog masters for a number of years - were often unavailable. ${ }^{223}$ Instead, rank-and-file policemen who took part in the investigation offered their accounts of the dogs' behavior at the defendant's home or during an identification parade; whether they pounced on the defendant or barked. ${ }^{224}$ These policemen could not speak to the dogs' pedigree, training, or reliability; nor could they testify concerning adherence to dog-handling protocols in the particular investigation. At most, they could attest to compliance with general lineup requirements, thus limiting the value of their crossexamination. ${ }^{225}$ Yet the inability to challenge their evidence proved to be one of the dogs' greatest advantages over human trackers: the scent that the dogs followed could be neither observed nor preserved, and unlike Bedouin trackers, the dogs' methods could not be scrutinized or undermined in court.

Palestine's courts admitted dog identifications even when the police had clearly breached handling and tracking protocols. ${ }^{226}$ In a 1936 murder trial, dog master Parker divulged on cross-examination that before conducting a two dog, ten person identification parade, he had permitted "a suspect

221. Ibid., 318. See also: "Death Sentence for Daylight Shooting," Palestine Post, June $11,1939,2$.

222. Compare to the situation in Kenya when dogs were employed: Cr. App. 44/52 Abdullah bin Wendo v. R. 20 East African Court of Appeal (EACA) 166 (1953). The court insisted that at minimum the handlers be available to testify.

223. See for example ISA M 276/22 (The witness testifying at trial was Kassen Eff. Abu Ghazaleh, a member of the Palestine Police, who interrogated the defendant. Concerning the dogs, he testified: "On 17/3/37 at 9:10 in the morning, the accused was put in a parade for identification by the Police dogs. The dog picked him out from amongst 7 persons after it had smelt the odour of the place where the large blood stains were found. The dog recognized him twice. After that, I charged the accused Mohammad Yasseen with the murder. He denied killing him. He said: 'I did not kill Shmuel Gottfried and I did not see him."')

224. Ibid.

225. The dog's techniques would be less at issue if the defendant confessed, as they often did. See Spicer, "The New Detective," 249.

226. Criminal Assize 8/36 Said Mustafa Abbas and Jamil Abu Imris v. Attomey General (August 11, 1936). 
person to come near the place in which there is a trace related to the crime." This raised fears of contamination and the possibility that the dogs - much like the Bedouin trackers in the Arlosoroff investigation - had followed spoors left at the scene after the crime. Although the judge deemed this breach "extreme negligence," he nevertheless admitted the evidence. The defendants were convicted despite the testimony of an eyewitness who named three other suspects. 227

How did judges in Palestine justify the admission of dog-tracking evidence especially given dog tracking's exclusion as insufficiently reliable in South Africa, and the Palestine government's initial pledge not to rely on such evidence in court? ${ }^{228}$ Although Dobermans may not originally have been expected to furnish evidence, political unrest soon after their arrival may have led the government to renege on its commitment. As the Tegart Report noted, during the Revolt the police were often unable to procure willing eyewitnesses; they could muster little more than the barking or pawing of a Doberman Pinscher to tie defendants to a crime. When dogs supplied the only proof linking alleged rebels to a crime, judges in Palestine may have been disinclined to exclude it.

Judicial reticence to exclude may have also stemmed from mounting pressures on the judiciary to help quell the unrest. A rare 1937 instance in which a magistrate declined to indict based on dog-tracking evidence resulted in parliamentry criticism of the government's mishandling of the Revolt. The criticism prompted the Secretary of State for the Colonies to demand a detailed report on the case from Palestine's High Commissioner. ${ }^{229}$

227. Ibid. The district court judge observed: "This is a queer evidence and it is extraordinarily not bad. The method through which the identification took place, however, is that the two accused were brought to the place of the incident, and their feet may have stepped near the place of the footsteps which are found there, and the dogs may have smelled their footsteps. The Court sees that it is a sign of extreme negligence to permit a suspect person to come near the place in which there is a trace related to the crime, and have the dogs then come and smell its odour.")They were sentenced to 10 and 15 years' imprisonment.

228. One possibility is that in the absence of juries, Palestine's judges trusted their professional ability to attach proper weight to such evidence questionable as it may have been. However, given how cautious Palestine's judges proved to be concerning other formal evidentiary requirements - where they often displayed greater rigidity than English judges presiding over juries this explanation seems somewhat unlikely. See for example: Criminal Appeal 160/37 Ali Jarad v. Attorney General, 5 Palestine Law Reports, at 111 (1938).

229. ISA M 276/22 (The magistrate decided not to bind the accused over for trial despite the fact that a police dog had picked him out at two separate identification parades based on the smell of a blood pool and a cigarette packet found at the crime scene. Josiah Wedgwood brought the matter to the attention of Parliament when questioning Secretary of State for the Colonies Ormsby-Gore, asking "what further steps are to be taken to put an end to the terrorism in Palestine which prevents convictions being obtained by the police?" The question 
Pressures on the judiciary materialized in two concrete ways. First, the looming threat of removal for judges who proved too critical of the government. Chief Justice Michael McDonnell, who was deemed by Palestine's High Commissioner to be "unhelpful" in quelling the Revolt, was forced to resign in 1936. This sent a clear message to his brethren on the limits of judicial independence in the colonies. ${ }^{230}$ Second, the threat of martial law, which would allow the executive to bypass the civil judiciary altogether, was imminent. ${ }^{231}$ Judges may have therefore considered the admissibility of canine evidence to be a lesser evil.

Once admitted in Palestine, dog-tracking proof became admissible in other parts of the British Empire as well. ${ }^{232}$ In 1953, the East African Court of Appeals deemed dog-tracking evidence admissible in all of British East Africa, provided that the dog master was available to testify regarding the dogs" training and about "the nature of the test employed."233 Judicial acquiescence in such questionable investigative practices contrasts sharply with the treatment of canine evidence in Britain during the same period.

\section{The Hounds Come Home}

\section{A. The Limited Relevance of Colonial Experience}

On August 25, 1937, London's Daily Express ran a sensational story: "Secret Bloodhounds Imported for "Yard." According to the article, two American bloodhounds were secretly imported and privately quarantined in Newbury. Closely guarded, the hounds were visited by Scotland Yard

prompted Orsmby-Gore to take special interest in the case, ordering Palestine's high commissioner to submit a detailed report on it).

230. For the expectation that the judiciary in Palestine be more "helpful, see "Palestine and the Commission," Times (London), July 23, 1936, 16 ("So far the High Commissioner has not declared martial law; but he may have to adopt this drastic measure, especially if the attitude of some of the Palestine Judicature is not more helpful than it has been hitherto."). For the exchange between the secretary of state for the Colonies and Chief Justice Michael McDonnell concerning the judiciary's obligation to be "helpful," see NAUK CO 733/313/1 (letter from Ormsby-Gore to McDonnell, July 9, 1936). For press coverage of McDonnell's forced resignation see "The Chief Justice," Palestine Post, October 22, 1936 and NAUK CO 733/313/1 (newspaper clippings from October 22, 1936 and onwards).

231. "Palestine and the Commission," Times (London), July 23, 1936, 16.

232. Cr. App. 44/52 Abdullah bin Wendo v. Reginam 20 EACA 166 (1953).

233. Ibid. The case involved the murder of a plantation watchman on a very dark night. The court ultimately acquitted the defendant because the victim's unreliable identification and noted that the dog handler had not testified in court, which deemed the dogs' identification inadmissible in this case. However, the court emphasized that the method itself was admissible provided that certain requirements were met. 
officials; however, an anonymous source informed the paper that their "duties cannot be disclosed." The newspaper reported that the dogs were "expected to alter completely present methods of tracking criminals in this country." 234

The article prompted the Home Secretary to demand a report on the matter. He was informed that the article was "founded on fact, but most of the details are wrong." 235 The American bloodhounds were part of an experiment commissioned by the Home Office in late 1934, just as the first Dobermans were approaching Palestine's shores. As part of a Committee on Detective Work under the chairmanship of Arthur Dixon (undersecretary in charge of police) a subcommittee was assembled to consider the police's employment of canines. ${ }^{236}$

When considering dog tracking, the British Home Office looked to their dependencies' experience. The subcommittee sought the opinions of de Villiers in South Africa and Spicer in Palestine. ${ }^{237}$ However, the subcommittee decided that to fully assess the method's suitability for Britain, it would conduct its own rigorous experiments in breeding, crossbreeding, and tracking. Foreign "successes" in other parts of the world were deemed only sufficient to make inquiry into dog tracking "worthy of pursuit," but insufficient to lead to the method's wholesale import. ${ }^{238}$ As the report to the Home Secretary noted, "After consideration of the use made of dogs abroad" the subcommittee members were "satisfied that an exhaustive study of this question would be well worth while." 239 The need to experiment locally had a nationalistic tinge as well: "the Committee did not lose sight of the possibility that it might be necessary to import some of these animals for experimental work under British conditions, but they thought that it would be well, in the first place, to explore the possibilities of using British breeds." 240

In 1935, Herbert Summers Lloyd, "one of the best known and most experienced trainers in the country" 241 was "commissioned to carry

234. NAUK HO 45/21003 (newspaper clipping in the archival file).

235. Ibid. (unknown author to Home Secretary, August 30, 1937).

236. Ambage and Clarke, Unbuilt Bloomsbury, 297, 302.

237. NAUK MEPO 2/4981 (de Villiers to Allan, January 9, 1935; Spicer to Allan, November 6, 1934).

238. HO 45/21003 (Report from July 31, 1935: "Some continental countries, notably Germany and Austria, have developed the use of dogs for protective purposes to a very large extent, and the South African Police have by cross-breeding evolved what appears to be a very satisfactory breed for tracking work in that country.")

239. Ibid.

240. Ibid.

241. Ibid. 
out. . . a systematic programme of experiments in breeding and training." 242 Granted $£ 500$ per annum for 4 years, Lloyd was commissioned to explore the use of dogs not only for tracking but also for other police work. The aim was to "evolve a dog which would have as good a nose as the bloodhound but would be more robust and less expensive to maintain," that could track, patrol, and protect. Fellhounds and Labradors were initially crossed for these purposes. ${ }^{243}$ It was under this program that the more "robust" American bloodhounds - so deeply implicated in slave hunts just a few decades earlier - were secretly brought to Britain. ${ }^{244}$

Despite its colonial successes, of more than thirty pure and crossbred dogs held at the Newbury kennels there was only a single Doberman, which Lloyd deemed "a failure." Still, he allowed, one could not really "form an opinion on this breed by this isolated case." 245 Given the South African experience, Lloyd allowed that in the future he "would be quite prepared...to give [the Doberman] an extensive and thorough trial." Perhaps reflecting an enduring preference for British breeds, his experiments focused primarily on the bloodhound. However, the fact that the standard imperial police tracker received such limited attention in Lloyd's experiments strongly suggests the inapplicability of colonial policing methods for the metropole.

The subcommittee's attempts to develop a single breed fit for both tracking and patrolling failed and were ultimately abandoned. ${ }^{246}$ More significantly, after 3 years of research, the subcommittee concluded that the "experiments with tracking dogs" had been "disappointing." Still, subcommittee members remained hopeful that "by judicious selection" they could eventually "evolve a strain of bloodhound, or a cross-bred hound...with a higher standard physique than that of the average English bloodhound" (which had been "bred for looks," rather than stamina or "inherent scenting powers."247) As a result, although Labradors began assisting the Metropolitan Police in patrol in 1938, the force did not incorporate tracking dogs until 1948.248 The failed

242. NAUK MEPO 5/112 (Committees for the Study of Dogs and their Use in Police Work, 1935-1937; undated and unsigned report).

243. Ibid.

244. Ibid.

245. Ibid.

246. Ibid.

247. Ibid. See also: HO 45/21003 (July 31, 1935). The subcommittee was particularly hopeful that attempts at a bloodhound-otterhound cross might in the future prove satisfactory.

248. "Police Dogs in London," Times (London), May 13, 1938, 13 (reporting the arrival of the first Labradors at Scotland Yard: "Tracking or picking up scent will not be their chief work"); and "Science to Help All Police" Times, February 20, 1940, 5 (explaining that because of the war, the center for dog training and experiment would not be funded). 
experiments in Britain did not, as we have seen, hinder the use of dogs in other parts of the Empire.

\section{B. Changing Attitudes Toward Dog Tracking}

Upon discovery that the Metropolitan Police was considering the employment of bloodhounds, The Times in 1938 pointed to the breed's enduringly dreadful image: "The popular conception of the bloodhound is of an awe-inspiring beast, strong, fierce, implacable; heedless of heat, cold, hunger or fatigue; demanding only a snatch of sleep and a hunk of raw flesh before starting off, with bloodshot eyes and swinging dewlap, in pursuit of its next victim." 249 The Lloyd subcommittee's secretive nature and the newspapers' sensational headlines concerning the import of American bloodhounds attest to the enduring aversion toward using dogs - and bloodhounds in particularto track humans in Britain.

The Second World War represented a turning point in public attitudes toward tracking dogs. During the Blitz, canines proved invaluable in locating victims under the ruins. For their assistance, several dogs were awarded the Dickin Medal for Gallantry. ${ }^{250}$ This helped to recast dogs as rescuers rather than hunters, which contributed to the expansion of Scotland Yard's Dog Support Unit (DSU) during and after the war. The dogs' heroism paved the way toward tracking dogs' incorporation into the DSU: The Unit's first tracking dog an "Alsatian" (more commonly known as a German Shepherd ${ }^{251}$ ) formally joined the force in 1948.252

During the postwar era, dogs were initially employed to pursue and tackle purse snatchers and to control hooligans and "subculture" rebellious youth such as Teddy Boys. ${ }^{253}$ Here, too, the psychological effects of the dogs were not overlooked. As one police source noted, dogs were seen to be "particularly useful in handling hooliganism because being controlled

249. "The Delicate Bloodhound," Times (London) March 3, 1938, 15.

250. Hannah Velten, Beastly London: A History of Animals in the City (London: Reaktion Books, 2013), 83.

251. See Aaron Skabelund, "Breeding Racism: The Imperial Racism of the 'German' Shepherd Dog," Society \& Animals 16 (2008), 354-71, at 355 (noting the British Kennel Club's rebranding of the German Shepherd as the "Alsatian" after World War I, because of growing animosity toward Germany).

252. "How Police Dogs Are Trained: Use in Tracking Criminals" Times (London), August 31, 1951, 2 ("The use of dogs to track and arrest criminals started in its present form in 1948.")

253. "Police Dogs' Captures" Times (London), July 15, 1947, 2; and "Successes in Use of Police Dogs," Times, June 17, 1954, 4. For a discussion of "Teddy Boys" as a subculture or tribus, see Andy Bennett, "Subcultures or Neo-Tribes? Rethinking the Relationship between Youth, Style, and Musical Taste," Sociology 33 (1999) 599-617. 
by a dog involved loss of face." ${ }^{254}$ With time, the police began using dogs to follow spoors left at crime scenes. ${ }^{255}$ By 1962, the Metropolitan Police was employing a "Flying Dog Squad" ("minivans connected by radio...containing two highly trained police dogs") that could quickly arrive at crime scenes throughout London, while footprints were still fresh. ${ }^{256}$

\section{Dog Tracking's Scientific Foundation and Admissibility}

Although Scotland Yard began employing tracking dogs in 1948, their evidence remained inadmissible in court. As the DSU expanded, however, both the Metropolitan Police and researchers convinced of the canines' accuracy aimed to ground dog tracking scientifically in a way that would satisfy judicial standards. ${ }^{257}$ By the early 1950s, John Rymer-Jones, Palestine's former Inspector General, was serving as Assistant Commissioner in the Metropolitan Police. He described the dogs' extensive use and the admissibility of their evidence in Palestine to his colleagues, raising hopes that English courts might follow. ${ }^{258}$ As Chief Inspector stanley Peck of New Scotland Yard observed,

The employment of dogs for Identification Parades was, I know, successfully used in Palestine when [Rymer-Jones] was Inspector General, but in this country, of course, such evidence is not accepted in the Courts. Knowing the infallibility of a dog's nose, I think the time has come to prove to the Justices that the selection of a human being by a dog is more certain than that made by another human being. There is no question of the human error creeping in with a dog. ${ }^{259}$

In 1953, Professor Hans Kalmus, of University College London's Galton Laboratory, took up the challenge of providing a scientific foundation for dog tracking. Kalmus designed a study to assess dogs' ability to distinguish between family members. Wishing not to raise false hopes, Kalmus warned that "While I am sure that such a study would be useful in this laboratory's search for factors concerning human individuality, I cannot promise that

254. "Police Ready to Use More Dogs," Times (London), February 28, 1958, 4.

255. Velten, Beastly London, 83; "New Methods to Combat Crime," Times, January 2, 1951, 2; "Bandit's Car Found," Times, August 5, 1949, 4; and "Police Ready to Use More Dogs," Times (London) February 28, 1958, 4.

256. "'Flying Dog Squad' for London," Times (London) December 29, 1962, 6.

257. NAUK MEPO 2/10507 ("Admissibility of Evidence Derived from Use of Tracking Dogs", 1963-1966).

258. NAUK MEPO 2/9438 (Kalmus to Rymer-Jones, March 26, 1954: "I remember you telling me that when you were in command [in Palestine], police dogs were extensively used and I gather from the daily papers that this is still the case.")

259. NAUK MEPO 2/9438, (Chief Inspector Peck to Chief Superintendent, July 18, 1953). 
anything of immediate forensic importance will necessarily emerge." However, perhaps trying to secure the Yard's cooperation, Kalmus articulated one way in which the study would not remain merely theoretical but might benefit law enforcement: "I am told that, as yet, identification by dogs is not admitted in British courts of law and that the police think it desirable that such identification should be admitted. An experimental treatment of the subject and its publication in a scientific journal might be the first step to establish such a practice in this country." 260

To prove scientifically the uniqueness of human scent and dogs' ability to identity and communicate it, Kalmus pursued a question first raised by Francis Galton in the nineteenth century ${ }^{261}$ : exploring whether dogs could distinguish between the scents of identical twins, the ultimate proof of uniqueness. ${ }^{262}$ To test his hypothesis, Kalmus recruited nine dogs: six Alsatians (four police dogs and two show dogs), a Doberman, a Labrador, and a Pointer. The thiry-one person sample of men, women, and children included only one non-Caucasian an African. Although Kalmus did not explain this aspect of his methodology in detail, it may be inferred from his experimental design: focused on differentiating between family members, the sole African subject was used as a preliminary control to determine whether each of the dogs was capable of distinguishing between races. The lack of racial diversity in the sample might also suggest the enduring assumption that Africans - and perhaps other foreign populations - were more odiferous than Britons. ${ }^{263}$

Kalmus's results exposed high inconsistencies in the dogs' performance. During his preliminary trials, seven of the nine dogs could not even distinguish between the scents of unrelated strangers. Although the two most talented dogs were successful in following the correct twin's trail, even they failed Kalmus's "handkerchief lineups," in which they were asked to retrieve the handkerchief of an individual they had previously sniffed. ${ }^{264}$

\section{NAUK MEPO 2/9438 (Kalmus to Peck, July 17, 1953).}

261. Francis Galton, "Anthropological Miscellany: The History of Twins, As a Criterion of the Relative Powers of Nature and Nurture," Journal of the Anthropological Institute 5 (1875), 391-406, at 395 ("It would be an interesting experiment of twins who were closely alike to try how far dogs could distinguish them by scent.")

262. Hans Kalmus, "The Discrimination by the Nose of the Dog of Individual Human Odours and in Particular of the Odours of Twins," British Journal of Animal Behavior 3 (1955): 25-31.

263. On the relationship between odor and otherness, see Jonathan Reinarz, Past Scents: Historical Perspectives on Smell (Urbana, IL: University of Illinois Press, 2014), in particular ch. 3 ("Odorous Others: Race and Smell").

264. Ibid. Many of the dogs retrieved the first handkerchief of a family member that they came across. In cases in which the individual's handkerchief was not part of the lineup, they invariably brought back another handkerchief nevertheless. 
Although Kalmus's results did not necessarily disprove his hypothesis concerning the distinctiveness of human scent, his experiments failed to establish dogs' ability to detect and communicate it. ${ }^{265}$ Inability to validate these aspects further delayed the admissibility of dog tracking evidence in the United Kingdom. Despite some support for its admissibility within legal academia in the following decade, the Metropolitan Police's stated policy remained not to rely on such evidence. ${ }^{266}$ It would take dog tracking four more decades - until 1995 - to be deemed admissible in England. ${ }^{267}$

\section{Conclusion}

The unique challenges of colonialism reshaped the boundaries of forensic inquiry in profound ways. Dog tracking spread as a method of policing and proof throughout the British Empire, even as it was rejected in the metropole. The stock thefts that plagued South Africa excused a practice deemed intolerable in contemporary Britain. Although racial difference played a lesser role in dog tracking's adoption in Palestine, admitting such evidence proved expedient in policing and prosecuting an uncooperative population during a period of anticolonial unrest.

Dog tracking's history does not fit neatly within the "empire as laboratory" paradigm of forensic science, whereby reformers in the metropole

265. NAUK MEPO 2/10507. The Metropolitan Police's stated policy in the 1960 s was that "before a person is arrested as a result of tracking by a police dog, there should be some other supporting evidence available." It was anticipated that otherwise "the evidence of the dog tracking may be strongly challenged by the Defence." (Chief Inspector to Superintendent, August 15, 1966).

266. A.H. Hudson, "Bloodhound Testimony," Criminal Law Review 10 (1963): 555-59; A.H. Hudson, "Bloodhound Testimony Again," Criminal Law Review 14 (1967): 110. "Evidence of Police Dogs: Ground of Admissibility," New Law Journal, July 26, 1966 (Citing the following cases: R. v. Montgomery [1966] N.I. 120 [Northern Ireland]; Patterson v. Nixon [1960], S.L.T. 220 [High Court of Judiciary, Scotland]; and R. v. Hass [1962] 35 D.L.R. $2^{\text {nd }} 172$ [British Columbia Court of Appeal]).

267. R. v. Pieterson and Holloway [1995] 2 Cr. App. Rep. 11. The decision addressed the admissibility of an Oxford Police dog handler's testimony concerning the actions of her dog Ben in an armed robbery investigation. The Lords observed that there was "no authority hitherto in English law as to the admissibility of evidence concerning a tracker dog." Drawing on precedents from across Britain's former empire - South Africa, Canada, New Zealand, and Ireland - Lord Taylor ultimately decided to admit such evidence, but it would be subject to two safeguards: first, a "Proper foundation must be laid by detailed evidence establishing the reliability of the dog in question." Ibid, 15. In addition to proof of the dog's training, the dog must be shown to be "a reliable pointer to the existence of a scent from a particular individual." Second, the jury would have to be instructed to "look with circumspection at the evidence of tracker dogs, having regard to the fact that the dog may not always be reliable and cannot be cross-examined." 
wishing to advance a novel technique advocated its employment first in the colonies or on others at home (such as convicted felons) to work out potential wrinkles and to make the method more palatable to the British public. ${ }^{268}$ Although the idea of using dogs to track criminals loomed large in the Victorian imagination and was disseminated through fiction and sport, the impetus for introducing tracking dogs in policing originated and later diffused mainly in the colonies, independently of direction from the metropole. Moreover, even after decades of imperial experience, the lessons and insights of the colonies bore only limited relevance for Britain itself. Dog tracking's employment in the colonies did not alter its repugnant image at home. Nor did it relieve reformers from scientifically establishing dog tracking anew before offering such proof in English courts. Although it purportedly relied on scientific universality for its validity, dog tracking was a method that from its inception and throughout its implementation was predicated upon - and often constructed - colonial difference.

268. Compare Cole, Suspect Identities, 93-96; Sengoopta, Imprint of the Raj, 190-193 (experimentation with fingerprinting in the colonies and on recidivists). 
